\title{
An Overview of the Immunological Defenses in Fish Skin
}

\author{
María Ángeles Esteban \\ Fish Innate Immune System Group, Department of Cell Biology and Histology, Faculty of Biology, University of Murcia, \\ Regional Campus of International Excellence “Campus Mare Nostrum”, 30100 Murcia, Spain \\ Correspondence should be addressed to María Ángeles Esteban, aesteban@um.es
}

Received 26 August 2012; Accepted 12 September 2012

Academic Editors: A. Bensussan, E. Flaño, J. D. Hayball, and P. Puccetti

Copyright ( 2012 María Ángeles Esteban. This is an open access article distributed under the Creative Commons Attribution License, which permits unrestricted use, distribution, and reproduction in any medium, provided the original work is properly cited.

\begin{abstract}
The vertebrate immune system is comprised of numerous distinct and interdependent components. Every component has its own inherent protective value, and the final combination of them is likely to be related to an animal's immunological history and evolutionary development. Vertebrate immune system consists of both systemic and mucosal immune compartments, but it is the mucosal immune system which protects the body from the first encounter of pathogens. According to anatomical location, the mucosa-associated lymphoid tissue, in teleost fish is subdivided into gut-, skin-, and gill-associated lymphoid tissue and most available studies focus on gut. The purpose of this paper is to summarise the current knowledge of the immunological defences present in skin mucosa as a very important part of the fish immune system, serving as an anatomical and physiological barrier against external hazards. Interest in defence mechanism of fish arises from a need to develop health management tools to support a growing finfish aquaculture industry, while at the same time addressing questions concerning origins and evolution of immunity in vertebrates. Increased knowledge of fish mucosal immune system will facilitate the development of novel vaccination strategies in fish.
\end{abstract}

\section{Introduction}

According to the FAO (Food and Agriculture Organization of the United Nations), presently $52 \%$ of the 600 wild fish species with economic value are heavily depleted, $17 \%$ overfished, and the $7 \%$ fully exploited. Supply from capture fisheries will be static over the next 30 years. A growing percent of world aquatic production derives from aquaculture, whose importance is set to increase dramatically as a result of overfishing of the world's waters and an increasing demand for seafood [1].

In fact, aquaculture production has increased from representing $9 \%$ of the fisheries resources in 1980 to a current $43 \%$, actually, and it is thought that production will need to double in the next 25 years, according to the FAO. The FAO promotes aquaculture not only for being an important source of money and employment, but also for its great contribution to food security and social development of many countries. The success of modern aquaculture is based on the control of the reproduction, a good knowledge of the biology of the farmed fish, on technology innovation, and on the development of a specific feed. Nevertheless, there are some important challenges to develop productive, feasible, and sustainable aquaculture in present superintensive systems. One of these challenges is that in large-scale production facilities where aquatic animals are exposed to stressful conditions, problems related to diseases and deterioration of environmental conditions often result in economic losses [2]. Control of such pathogens (most of which are bacterial) in fish farms has been routinely achieved by the administration of antimicrobial agents. However, the excessive use of these antimicrobials has led to the emergence of antibioticresistant bacteria, due to those drug-resistant strains carrying a transferable R-plasmid, making the treatments less successful [3]. In addition, the transference of resistant genes between bacteria (reviewed [4]) could have a risk to human health [5]. The modern aquaculture industry demands alternative preventative practices that may help to maintain a high animal welfare as well as a healthy 
environment, resulting in better production and higher profits. Furthermore, the emergence of generic "green" values among consumers and a new heightened environmental awareness make the development of a sustainable aquaculture necessary. A better knowledge of the immune system of cultured fish will help to achieve these aims.

The vertebrate immune system includes lymphoid organs that, according to their ontogeny and functional characteristics, are considered to be either primary or secondary. One of the secondary organs is the MALT (mucosaassociated lymphoid tissue) [6]. Among MALTs particular interest (given its extension) has been given to the GALT (gut-associated lymphoid tissue) [7].

The fish immune system, comprised of numerous distinct and interdependent immune components, is necessary for organisms to defend themselves against invading pathogens [8]. Every component of the immune system has its own inherent protective value, and the final combination of these components is likely to be related to a satisfactory immune response [9]. According to anatomical location, the MALT in teleost fish is subdivided into gutassociated lymphoid tissue (GALT), skin-associated lymphoid tissue (SALT), and gill-associated lymphoid tissue (GIALT) [10]. Mucosal immunity in fish is a very rarely studied research field, although there is currently great interest in this knowledge, and the study of the GALT has intensified in recent years $[11,12]$. The fish MALT has defence mechanisms (both innate and adaptative) that constitute the first line of defence opposite to the infectious agents [12-16]. Since the majority of the infectious agents affects or initiates the process of infection in the mucous surfaces, the mucosal immune response plays a crucial role in the course of the infection [17], and different studies have begun to examine their cellular and molecular composition in different species [18-20]. Skin, gill, and gut constitute a large area (much greater than that of other vertebrates) for the possible invasion of pathogens [21], which is also influenced by the fact that there is an intimate contact between these animals and the aquatic environment.

To know the immune mechanisms which exist in a constitutive way in the mucosa, to know which mechanisms are induced, and to understand the cellular interactions that happen after an infection are all very important goals for the development of new vaccines capable of generating robust immune responses in the mucosa. For that, a deeper knowledge of this immunity is needed in order to prevent and control infectious diseases [22]. This paper will focus on the fish skin mucosa immunological defences as a very important part of their immune system [23] and provides a short overview of the field. Because it is a big topic, this is not meant to be an exhaustive report, but seeks rather to highlight how it has developed research in this field and what are the most current lines of study. This is an area of research that began in the 70s and is still highly topical for many reasons which will be explained. First, the results obtained during the early years will be analyzed, and this paper will end with the latest techniques.

\section{Teleost Skin}

Body surfaces of multicellular organisms are defended by epithelia, which provide a physical barrier between the internal milieu and the external world. Skin is the structure that covers the body and protects it not only from the entry of pathogens or allergens, but also from the leakage of water, solutes, or nutrients. These outside-in and insideout barrier functions are dependent on the epidermis, a stratified cellular sheet. While mucus covers the epidermis in fish and amphibian tadpoles, differentiated cornified cellular sheets (stratum corneum) constitute the outermost epidermal barrier in amphibian adults, reptiles, birds and mammals [24].

Teleost skin in particular is unique and histologically diverse [25]. It is very different from that of mammals, because it secretes mucus which is involved in immune functions [10]. Its structure and function reflect the adaptation of the organism to the physical, chemical, and biological properties of the aquatic environment and the natural history of the organism. The aquatic environment is rich in pathogenic organisms [26]; hence, the skin of aquatic vertebrates is extremely important as the first line of defence against the invasion of environmental pathogens, and it is just important to the respiratory and digestive organs. Because of the intimate contact of fish with the environment, cutaneous diseases are relatively more common in fish than in terrestrial vertebrates and are one of the primary disease conditions presented to the aquatic animal practitioner [27].

The integument or skin is the envelope that not only separates and protects a fish from its environment, but also provides the means through which most contacts with the outer world are made. It is a large organ and is continuous with the linings of all body openings and also covers the fins. In addition to being a mechanical barrier, it represents a metabolically active tissue [28]. In fact, fish integument is a multifunctional organ, and its components may serve important roles in protection, communication, sensory perception, locomotion, respiration, ion regulation (reviewed by [29]), excretion, and thermal regulation (reviewed by [30]). These functions are possible due to the skin's complex structure and cell composition [30]. All of these functions (mainly immunity, osmoregulation, respiration, and excretion) are especially significant in fish larvae because the importance of the skin in early developmental stages also relies on the fact that surface to volume ratio is high in early stages and decreases during the development [31]. Although numerous studies have focused on the histology and cytochemistry of the epidermis of adult teleosts [review in [28, 32-36]], the structure of the larval skin has been studied only in a few species [37-41]. According to the existing data, the larval skin of teleosts is a thin two-cell layer (including mucus/goblet cells and the chloride cells/mitochondrial rich cells/ionocytes) lying on a basal membrane and overlying an extensive haemocoel (reviewed by [31]). In yolk sac larvae, the mucus cell content appears composed of exclusively neutral (Periodic acid-Schiff stain (PAS) positive) intracellular glycoproteins $[38,41]$. Goblet cells of the corporal skin were evident on days 15-20 of larval development of Senegal sole 
(Solea senegalensis) and contain $\mathrm{N}$-acetyl glucosamine and/or sialic acid [42].

In general, the layers of tegument of adult teleosts are the cuticle or mucus layer (with a very complex composition), which have bacteria forming the microbiota (not considered in the present paper), the epidermis (a squamous stratified epithelium with goblet cells) and the dermis (with two layers, the hypodermis or stratum spongiosum, a frequent site of development of infectious processes and the innermost layer or stratum compactum) [43]. The nonkeratinized epidermis, 5-10 cells thick, consists entirely of live cells, of which the majority is squamous cells and the minority is mucous cells [23]. The squamous cells are characterized by numerous desmosomes and associated cytoplasmic filaments [44] with only minimal quantities of keratin in the cells of the superficial layer, whose cells show microridges that contain mucus and antibacterial substances secreted to the surface from mucous goblet cells located in the intermediate stratum of the epidermis [45]. The dermis is mainly composed of dense connective tissue with a large amount of collagen fibres, although it typically contains relatively little of the connective tissue found in tetrapods. Instead, in most species, it is largely replaced by solid, protective bony scales. Cartilaginous fishes have numerous tooth-like denticles embedded in their skin in place of true scales. Pigment cells are of three types: melanophores, iridophores (guanophores), and lipophores [38]. Although melanin is found in the skin of many fish species, the epidermis is often relatively colourless. Instead, the colour of the skin is largely due to chromatophores in the dermis, which, in addition to melanin, may contain guanine or carotenoid pigments [46]. The hypodermis consists of loosely organized collagen fibres and rich supply of vessels and, as the innermost layer, is closest to the striated muscle underneath the skin. The origins of these skin layers of teleost are still unknown. In this sense, some works have renewed interest in the teleost dermomyotome [47], which was initially characterized in the late 19th century. New works are studying the primary myotome morphogenesis, the relationship between the primary myotome and the dermomyotome, as well as the differentiation of axial and appendicular muscles and dermis from the dermomyotome (reviewed by [48]). Concretely, some of the zebrafish dermomyotome precursors examined recently by lineage labelling were reported to give rise to "dermis" cells, based only on their position [49]. As the teleost dermis has not been well characterized in any species, these results must be viewed as preliminary [48].

Besides normal epithelial cells, fish epidermis contains various types of unicellular glands [50]. Most studied are the goblet (mucous) cells which are responsible for the production of the mucosal layer [51], although some other mechanisms could also be involved in the production of mucous components, possibly including transfer of material from the secondary circulatory system [52]. Due to this main function of secreting mucus, mucous cell densities in skin seem to act as a sensitive first line of immune defence parameter in fishes [53]. Besides mucus-secreting goblet cells, cells that produce a more watery, serous fluid may also be present in the epidermis [54]. Furthermore, some bony fishes possess holocrine, multicellular poisonous glands usually associated with spiny rays [55]. The number of mucous cells of fishes is affected by many stressors, and there is now evidence that the enumeration of the skin mucous cells of fishes can be used to monitor stress in them [56]. Both the number of goblet cells and the composition of the mucus which they produce may vary depending on their location. On the other hand, fine structural studies have demonstrated that the epidermis of fishes may have two different types of glandular cells, namely, goblet cells and club cells [26, 57]. The slipperiness of the mucus is considered to be a result of the presence of high molecular weight gel-forming macromolecules, and it is assumed that the predominant gel-forming macromolecules in mucus are glycoproteins. While the mucous cells are present in all fish epidermis, the club cells are considered a more specific cell population, and they are only found in the epidermis of some fish species [57]. The club cell contents are largely proteinaceous, with comparatively little carbohydrate components. Their functions are not well defined, but some protective roles have been suggested [58, 59]. Curiously, several studies also have provided evidence that preparations from fish skin secretions can stimulate the rate of wound healing in animals and the healing of diabetic foot ulcers in humans [59-64]. More studies are needed to elucidate the nature of the molecules responsible wound healing as well as the type of cells involved in their synthesis and/or secretion.

Fish epidermis encompasses a variety of viable cell types (enumerated above), of which the most important one structurally is perhaps the motile keratocyte $[32,51,65]$. Keratocytes can cover fish skin wound surfaces with a new protective layer of cells within hours after wounding by rapid migration from the surrounding wound margins [66, 67]. In addition to their migratory activity, different cell types present in fish epidermis are shown to internalize particular matter such as bacteria and other particles. The characteristics combine to suggest these cells as an important contributor to the fish innate immune response, serving to protect against microorganisms and other potentially harmful substances from the surrounding water $[68,69]$. The keratocyte function implies wound repair is related to the fact that most animals have the ability to repair an epidermal lesion after an infection or a fight in the wild. In fact, the epithelialization of the wound gap in fish species involves changes in the surface architecture of the epithelial cells. As a quick response to injury, profuse mucous secretion and accumulation are observed on the surface of the adjacent epithelial cells, which is also associated with the protective function of mucus against pathogenic microorganisms [7072 ]. Furthermore, a very noticeable property of teleost fishes is that they can fully regenerate largelysevered appendages with different tissues, as can several aquatic urodele amphibians. This regeneration is an exceptional and remarkable cellular event already noticed in 1900 by T.H. Morgan for regenerating fins. Fin regeneration is a rapid process in which the wound is first healed by the rapid migration and rearrangement of the epithelial cells of the stump to cover the surface of the cut, leading to the formation of the wound epidermis, an inevitable process after lesion (reviewed by [73]). 
At present, it is assumed that cell lines provide an important biological tool for carrying out multiple investigations into physiology, virology, toxicology, carcinogenesis, and transgenics. Teleost fish cell lines have been developed from a broad range of tissues (ovary, fin, swim bladder, heart, spleen, liver, eye muscle, vertebrae, and brain) including skin (reviewed by [74, 75]), and most fish cell lines originated from normal tissues. Some permanent skin cell cultures from different fish species have been established, and even one cell line XM was initiated from skin and fin tissue of fish melanoma [76]. Last year Rakers et al. [77] demonstrated that it was possible to integrate freshly harvested rainbow trout (Salmo gairdneri)scales into fish skin cell cultures, and antibody staining indicated that both cell types proliferated and started to build connections with the other cell types. As they suggest, perhaps this is the first step to generate an "artificial skin" with two different cell types, and, in the future, similar studies could lead to the development of a three-dimensional test system [77].

\section{The Cutaneous Mucus Layer}

The mucosal surfaces of fishes (gill, skin, and gastrointestinal tract) form a thin physical barrier between the external environment and the internal milieu, and they are important sites of microbial exposure. Host defence mechanisms and their epithelia (with living cells) are covered by a protective mucus overlay $[65,78]$. Cutaneous mucus is considered the first line of defence against infection through skin epidermis $[16,65]$.

The fish skin mucus acts as a natural, physical, biochemical, dynamic, and semipermeable barrier that enables the exchange of nutrients, water, gases, odorants, hormones, and gametes. Concomitantly, mucus plays a critical role in the defence mechanism of the fishes by also acting as a biological barrier [79-81]. Skin mucus has evolved to have robust mechanisms that can trap and immobilize pathogens before they can contact epithelial surfaces, because it is impermeant to most bacteria and many pathogens [82]. This occurs because in this mucus layer, particles, bacteria, or viruses are entrapped and removed from the mucosa by the water current [83]. Furthermore, mucus in most fishes is continuously secreted and replaced, which prevents the stable colonization of potential infectious microorganisms as well as invasion of metazoan parasites [84]. Sometimes the mucus layer can be shed or digested; thus pathogens must move "upstream" through the unstirred layers of mucus adhering to the cells on the epithelium surface or penetrate a mucus "blanket" before it is shed [82], although more frequently mucus prevents the pathogen adherence to the underlying tissues being an indispensable barrier in the self-defense system of fishes $[8,85]$. An often underappreciated dynamic property of mucus is its ability to maintain an unstirred layer of mucus adjacent to epithelial surfaces despite vigorous shearing actions (such as swallowing, coughing, intestinal peristalsis, and copulation) [82].

Mucus is a complex fluid, and its composition varies throughout the epithelial surface. As the skin mucus is exposed to the surrounding outer environment, proteins in the skin mucus are required to maintain their activities under severe conditions such as higher temperature and hydraulic pressure [86]. Mucus is a viscid (sticky) gel; there are few surfaces to which it does not stick. The adhesive actions of mucus are used by many organisms from bacteria to barnacles and snails to adhere to the surfaces on which they live. Mucus is also used by small fishes to collect nutrients suspended in water [82]. Lipids in mucus secretions, including covalently attached fatty acids, contribute to fiber-fiber interactions that markedly increase the viscoelasticity of the gel, which has been studied on evolved vertebrate's gastric mucus [87]. The thickness of the mucus blanket is determined by the balance between the rate of secretion and rate of degradation and shedding. Toxic and irritating substances can greatly stimulate mucus secretion, increasing the thickness of the mucus blanket [82]. Small amounts of mucus are normally present on the skin of some fishes, including sharks [88].

The composition and characteristics of skin mucus are very important for the maintenance of its immune functions. Simply by being slightly more hydrated, saliva and tear fluid have markedly lower viscoelasticity and are readily penetrable by motile bacteria. Mucus transport requires wellregulated viscoelasticity which is controlled by hydration [82]. Thus mucosal epithelia must somehow regulate the viscoelasticity of secreted mucus gels, and it is likely that most mucosal epithelia do this in part by regulating the ionic environment to regulate mucus hydration and hence viscoelasticity [89]. This has been most carefully investigated in airway mucus [90-93]. Many other factors contribute to regulation of mucus viscoelasticity, including secreted lipids, trefoil factor, $\mathrm{pH}$, calcium, and nonmucin glycoproteins [94].

The different functions that have been suggested for fish mucus and its role as a clue component of fish immunity have been considered. Its frontier and first line defensive role in disease resistance has been studied [36, 65]. In addition, skin mucus provides a medium in which antibacterial mechanism may act [95]. Fish skin mucus thus serves as a repository of a variety of biologically active substances as well as numerous defensive molecules of both the innate and acquired immune system [18, 80, $81,96-99]$. Mucus performs a variety of functions (besides inhibition of the invasion and proliferation of pathogenic microorganism) including ion regulation, osmoregulation, lubrication $[8,65,81,100]$, and parenteral care behaviour [101]. The antimicrobial property of epidermal mucus against infectious pathogens (bacteria and viruses) has been demonstrated in different fish species $[8,84,102-105]$, and increased expression of one or more of the above-mentioned antimicrobial components in fish epidermal mucus has been observed following microbial stress [106, 107], thus supporting the role of epidermal mucus in protecting fishes from infectious pathogens.

Mucus composition varies among fish species. Furthermore, mucous cells and the compositions of the mucus they produce are influenced by endogenous factors (e.g., sex, developmental stage) and exogenous factors (such as stress, acid and infections) [108, 109]. In some occasions, especially when fish specimens are frightened or injured a high amount 
of proteins are present on mucus. The epidermis of such fish secretes a gel-like material which adheres to the skin even when they swim at varying speeds and for several days. For example, a catfish caught 48 hours after scraping the opaque proteinaceous gel did not elaborate more of the gel, but secreted a transparent, viscous, water-soluble solution, which is reminiscent of mucus. Similarly, the epidermal gel secretion of Arabian Gulf catfish (Arius bilineatus) is unlike what can be generally termed mucus. Over $85 \%$ of the dry weight of the gel secretion is protein, with lipids $(13.4 \%$ of the dry weight) and only small amounts of carbohydrates and nucleic acids. The epidermal secretion of other species (Arius tenuispinis) is more viscous and glue-like compared with that of $A$. bilineatus although their biochemical and pharmacological properties of both skin secretions appear to be similar [110]. More studies are needed to realize the biochemical characterization of the fish gel-like secretions different from normal mucus.

There is a limited knowledge about the defence mechanisms of the epidermal mucus of fishes, although both constitutive and inducible innate defence mechanisms are involved [8]. A description of the main components of the immune system found in fish mucus is now enumerated.

3.1. Mucins. The most abundant components of the mucus layer are high molecular weight, filamentous, highly glycosylated glycoproteins (some $50 \%$ of their dry weight can consist of carbohydrate chains) called mucins [35, 111]. Mucins are strongly adhesive, play a major role in the defence of the mucosae $[112,113]$, form a matrix in which a diverse range of antimicrobial molecules can be found [114], and impart viscoelastic and rheological properties to mucosal layers [115].

Although there is extensive information in literature on the fish mucins $[50,116]$, the carbohydrate nature of the glycoproteins in the unicellular glands in fish epidermis has not been fully characterized. One of the most complete works includes a histochemical study using both conventional carbohydrate histochemistry (periodic-acid, alcian blue) as well as a battery of fourteen fluorescein-isothiocyanate-(FITC-) labelled lectins. The lectins used were: mannosebinding lectins (Con A, LCA and PSA), galactose-binding lectins (PNA, RCA), N-acetylgalactosamine-binding lectins (DBA, SBA, SJA and GSL I), N-acetylglucosamine-binding lectins (WGA and WGAs), fucose-binding lectins (UEA), and lectins which bind to complex carbohydrate configurations (PHA E, PHA L). This study has permitted to identify the glycoconjugates present in the skin of a catfish (A. tenuispinis), and the results confirm that mucous goblet cells contain a considerable amount of glycoconjugates in all locations of the skin, whereas the other unicellular gland types, the club cells, lacked these glycoconjugates. The mucus produced by the epidermal goblet cells of this species is rich in mannose, $\mathrm{N}$-acetylgalactosamine, and $\mathrm{N}$ acetylglucosamine residues [117].

3.2. Innate Immune Components. As it has been previously indicated, for aquatic animals the skin is a major route of entry for infectious pathogens. Therefore, the skin mucus of fishes contains many kinds of biologically active (including defensive) molecules $[9,18,25,65,85,96,118]$. A review of literature reveals that not much attention has been given to the comparative biochemical analysis of innate immune parameters of fish skin mucus, although the distribution of some immune components and their possible role in defence have been reported in different fish species (see [65] for review, [18, 25, 80, 119]). Many substances with biostatic and biocidal activity (e.g., complement, C-reactive proteins, proteases, lectins, lysozyme, haemolysins, agglutinin, proteolytic enzymes, antimicrobial peptides, antibodies, immunoglobulins) are present and have been identified in the fish epidermis and/or skin mucus $[9,18,25,85,96$, 120]. Although the protective role of the epidermal mucus of fishes has been known for many years $[8,100]$, of great interest at the present is to see the skin mucus as a source for isolation of new and potent antimicrobial components [121]. A brief overview of the most studied immune components of fish mucus is now presented.

3.2.1. Enzymes. Perhaps, the most studied enzyme present in fish mucus is lysozyme. Lysozyme (N-acetylmuramide glucanohydrolase or muramidase) is a ubiquitous bactericidal enzyme identified in a wide range of organisms including fishes. Lysozyme is present in mucus, lymphoid tissue, and serum of most fish species, but not in others (such as cod and wolfish) $[119,121,122]$. The bacteriolytic activity of lysozyme in fish skin mucus and other tissues contributes to its host defence mechanism against bacterial infection $[80,123,124]$. Three or two isoforms of lysozyme were detected in skin mucus of different fish species [119].

Significant differences in the levels of lysozyme in skin mucus have been detected, depending on the fish species investigated [119] as well as on the environmental conditions. For example, lysozyme activity in skin mucus of Atlantic salmon (Salmo salar) specimens reared in freshwater was significantly higher than that found in the specimens from the same fish species reared in seawater [25]. Subramanian et al. [80] demonstrated higher levels of lysozyme in skin mucus of seawater fish species than those that inhabit freshwater. On the other hand, a consistently high level of lysozyme activity in the skin mucus of olive flounder (Paralichthys olivaceus) was observed throughout the sampling period, irrespective of changes in the water temperature. Furthermore, the lysozyme activity showed no significant correlation with other immune substances, which suggest that the lysozyme is constitutively secreted in the skin mucus of this fish species [125].

Acid and alkaline phosphatases, which are important lysosomal enzymes and are associated with the innate immune system in fishes, have also been identified in fish skin mucus [119]. As it was indicated previously for lysozyme, significant differences in the specific activities of these enzymes were observed among specimens [119]. Increased activities of phosphatases were demonstrated in epidermal cells during skin regeneration related to cutaneous wound healing in the catfish (Heteropneustes fossilis) 
[126-128] and in Atlantic salmon mucus during parasitic infections or stress $[25,129]$ and were considered to play a protective role in the initial stage of wound healing in the common carp (Cyprinus carpio) [128, 130]. Furthermore, alkaline phosphatase has been demonstrated as a potential stress indicator in skin mucus of Atlantic salmon [129]. As it was previously indicated for lysozyme, in a recent study no significant relationship was observed between the phosphatase activity and other mucosal parameters [125].

The activity of some other enzymes, such as the cathepsins, has been described in eggs and larvae of sea bass, cod, and salmonids. Cathepsins may have a bactericidal role in the skin of fishes, as has been demonstrated in Japanese eel (Anguilla japonica) [131] and catfish [132]. A unique copper and zinc super oxide dismutase (SOD) was found and isolated from plaice (Paralichthys olivaceus) skin, and from other sources reported so far, its properties were very different from those of SOD [133]. Esterases have also been identified in fish mucus [119].

Different enzymatic activities were found on gilthead seabream (Sparus aurata) and sea bass (Dicentrarchus labrax) mucus by using the Api Zym strips: Phosphatase alcaline, Esterase (C4), Esterase Lipase (C8), Leucine arylamidase, Valine arylamidase, Trypsine, Phosphatase acide, Naphthol-AS-BI phosphohydrolase, beta-galactosidase, beta-glucuronidase, N-acétyl-beta-glycosaminidase, and alpha-fucosidase. Besides, cystine arylamidase and betaglucuronidase have also been identified in gilthead seabream mucus [134]. New studies will provide new data on the enzymes present in fish mucus and fish epidermis.

3.2.2. Proteases. Based on the catalytic mechanism, proteases are categorized into serine, cysteine, aspartic, and metalloproteases [135]. Serine protease comprises more than $25 \%$ of the complement system [136] and is reportedly one of the major mucus proteases in several fish species [119]. Proteases such as trypsin (serine protease), cathepsin B and $\mathrm{L}$ (cysteine proteases), cathepsin $\mathrm{D}$ (aspartic protease), and metalloproteases have also been identified in fish skin mucus $[25,80,119,132,137-141]$. Proteases in skin mucus are involved in the natural resistance of fish to infection [85]. The release of proteases into skin may act directly on a pathogen (they can kill bacteria by cleaving their proteins) or may prevent pathogen invasion indirectly by modifying mucus consistency to increase the sloughing of mucus and thereby the removal of pathogens from the body surfaces [142]. Proteases also activate and enhance the production of other innate immune components present in fish mucus such as complement, immunoglobulins, or antibacterial peptides $[132,140,143]$.

Recently, the skin mucus of five Indian carp inhabiting different ecological niches was analyzed in order to characterize the relationships between potential innate immune factors (such as lysozyme, proteases, phosphatases, esterase and sialic acid) and environment. The results demonstrated that the enzyme activities were high in bottom dweller species (C. punctata and C. mrigala) and low in clean water inhabiting species (L. rohita and C. catla), while an inverse relationship was observed between the level of enzyme activity and the sialic acid content in these fish species [119]. The significance of the results will require further research.

3.2.3. Antimicrobial Peptides. Antimicrobial peptides (AMPs) are increasingly recognized as a critical component of the host's defence against infection. AMPs are antibiotics that have been isolated from a multitude of organisms ranging from microbes to plant and animal species $[144,145]$. To date, more than one thousand AMPs have been characterized (http://www.bbcm.univ.trieste.it/ tossi/). The AMPs show variations in their biochemical properties such as amino acid sequences, length, and structure, yet they share several common features. They display a broad spectrum of activity against numerous pathogenic organisms including Gram-positive and Gram-negative bacteria, yeast, fungi, enveloped viruses, and parasites with little or no toxicity to host cells. They also they inhibit DNA, RNA, and protein syntheses [146]. These AMPs are present in tissues exposed to microorganisms such as mucosal surfaces and skin $[100,140,147-150]$ and immune cells such as mast cells $[151,152]$. Although teleost mast cells are abundant around blood vessels and host-environment interfaces such as the skin, gills, and alimentary tract, their function in defence is not clearly defined. AMPs are produced constitutively or induced upon infection in fish epidermal mucus to defend against invading pathogens $[153,154]$.

While research has shown a vast number of AMPs in the mucus of numerous amphibians and mammalian species including humans [155], relatively few families of fish have been investigated so far for the presence of mucosal AMPs [156]. However, several types of AMPs have been identified from mucosal tissues or immune cells of a number of teleosts, and they are, at present, considered a very important part of the mucus and skin barrier function $([114,157]$, reviewed by [158]).

Alpha-helical amphipathic peptides are very common in fish, and they have been recently reviewed [159]. The first fish family of AMPs to be discovered was the $\alpha$-helical pardaxins, which were isolated from the skin glands of Red Sea Moses sole (Pardachirus marmoratus) $[159,160]$. Most fish $\alpha$-helical peptides are members of the piscidin family, which includes the pleurocidins and piscidins [159]. A few examples of AMPs that have been identified in fish epidermal mucus include pardaxin [160], pleurocidins, which are 25-residue peptides first isolated from the skin mucus of winter flounder (Pleuronectes americanus) [147], parasin 1 [153], hipposin [149], oncorhyncin III [161], oncorhyncin II [144], SAMPH1 [162]. S30 from skin secretions of Oncorhynchus mykiss [148] and three ribosomal-derived proteins and peptides (namely, L40, L36A, and L35) isolated from the epidermal mucus of Atlantic cod (Gadus morhua) [114]. Piscidins are 22-residue AMPs that were originally isolated from mast cells of hybrid striped bass Morone saxatilis male $\times$ Morone chrysops female and now known to be present in other fish species [148, 157, 163, 164]. Using an antibody specific for the conserved $\mathrm{N}$-terminal amino acid sequence of piscidin 1 , an immunohistochemical study has been carried out 
on skin, gill, and gastrointestinal tract of thirty-nine teleost fish species representing seven different orders. Nine fish species were piscidin-positive, with all of these species being in the Perciformes, the largest and most evolutionarily advanced order of teleosts. Piscidin-positive cells were identified in species belonging to the families Moronidae, Serranidae, Sciaenidae, Siganidae, and Belontidae [157]. Examples of piscidins are also dicentracin from the European bass (Dicentrarchus labrax) [165], chrysophsins from red sea bream (Chrysophrys major) [166], and epinecidin from the orange-spotted grouper (Epinephelus coioides) [167]. Lee et al. [168] determined the solution structure of piscidin1 , and then piscidin-2 was found to cause cell membrane damage to three fungal strains known to cause infections in humans [169]. Piscidin-immunoreactive cells were most common at sites of pathogen entry (including the skin, gill, and gastrointestinal tract), and immunopositive cells were usually most consistent with mast cells [151]. In some species, the granule appearance and tinctorial properties diverged somewhat from those of a typical piscine mast cell and are found in acidophilic phagocytes localted in gill, skin, stomach, and intestinal epithelia [163]. In gilthead seabream, piscidins are stored in the granules of the phagocytes and are delivered to the phagosome following uptake of bacteria by these cells [163]. In addition, rodlet cells have also been identified as piscidin-positive in one member of the family Cichlidae. This study was the first one which identified in rodlet cells a host-associated chemical biomarker [157]. All piscidins show broad-spectrum antimicrobial activity, probably killing cells via toroidal-pore formation [151, 170, 171]. Although attractive as potential candidates for topical application use because of their activity at high salt concentrations [172], the disadvantage of piscidins in this regard is their haemolytic and cytotoxic properties [173].

Amongst the cysteine-rich AMPs in teleost fish are three families: cathelicidins, defensins, and LEAPs [151]. By screening cDNA libraries or by using molecular methodology, putative cathelicidins have been found from rainbow trout [159], Atlantic salmon [174], Arctic char (Salvelinus alpines), Atlantic cod, and brook trout (Salvelinus fontinalis) [175]. Moreover, cathelicidin genes have been reported for jawless fish, namely, the Atlantic hagfish (Myxine glutinosa) [176]. Little information is available with respect to the native peptides, but synthetic rainbow trout cathelicidins are active against Gram-positive and Gram-negative bacteria [174].

Defensins from teleost fishes have been identified by molecular methodologies rather than purification of the native peptides in several fish species $[112,177-181]$. Zhou et al. [179] used EST and complete genome data to identify defensins from zebrafish (Dario rerio) and pufferfish (Takifugu rubripes) that resemble the $\beta$-defensins of birds and mammals. Falco et al. [182], using a recombinant protein based on rainbow trout defensin, found it to be antiviral against viral haemorrhagic septicaemia rhabdovirus (VHSV), one of the most troublesome diseases in fish aquaculture. More recent studies have cloned three novel $\beta$-defensins from rainbow trout, all of which appear to be constitutively expressed but increase in expression during bacterial and simulated viral challenges [180]. Similarly, a $\beta$-defensin-like gene from the olive flounder has been identified, which is expressed in larval fish just one day after hatching, although the expression declines between onethirty-five days after hatching [183]. Moreover, $\beta$-defensin expression in juvenile fishes is induced under conditions of bacterial challenge, and the recombinant peptide suppresses the growth of Escherichia coli [183].

The last major group of cysteine-rich AMPs from fishes is the LEAPs (liver-expressed antimicrobial peptides) [159], the acronym reflecting the original identification of the peptide family in the human liver [184]. Peptides belonging to the LEAP family include hepcidins from several species (e.g., winter flounder, turbot, and red sea bream), Sal-1 and Sal-2 from Atlantic salmon, JF-1 and JF-2 from Japanese flounder, and LEAP-2 from catfish and trout (reviewed by [159]).

Despite the intensive research on AMPs in animals, there is still surprisingly little data documenting their in vivo antimicrobial upregulation $[185,186]$. Low levels of antimicrobial peptides from healthy specimens or other factors such as $\mathrm{pH}$ could be the reason for difficulty in isolating antimicrobial peptides/polypeptides from mucus [121]. One of the scarce studies available demonstrated that the challenge of channel catfish (Ictalurus punctatus) with ich resulted in potent upregulation of a suite of AMPs in the skin (the total antibacterial activity response peaked at seven and fourteen days after challenge), including at least one polypeptide (HbbP-1) that is highly lethal to not only ich [187], but also to Tetrahymena pyriformis (a parasitic ciliate) and the important marine ectoparasite Aphyosemion ocellatum [188]. Similarly, intraperitoneal injection of either Freund's complete adjuvant (FCA) or live T. pyriformis upregulated multiple AMPs expression in channel catfish skin and total antibacterial activity peak on day seven following injection [189]. The mechanism(s) involved by which these AMPs may have enhanced expression at sites distal from the location of immunostimulant administration is unknown, but might be analogous to that observed when immunostimulants are administered to the skin and result in enhanced protection against infection at distal sites [190]. One possibility may imply the Langerhans cells. They are found in the outer layer of the skin, increase their baseline rate of migration out of the epidermis in response to stimuli such as contact sensitizers, inflammatory cytokines, and adjuvants (tumor necrosis factor alpha (TNF- $\alpha$ ) and interleukin-1beta (IL-1b)), and travel to inductive sites of the immune system [191].

Recent advances in understanding the mechanisms of their antiviral action indicate that AMPs have a dual role in antiviral defence, acting not only directly on the virion, but also on the host cell. Despite the acute problems of viral diseases and restrictions in using chemicals in aquaculture, few attempts to assess the antiviral activities of fish AMPs have been reported, in spite of the ones that have been successful. In addition, because fishes rely more heavily on their innate immune defences than mammals, they might constitute a potential rich source of antiviral compounds for fighting against mammalian viral infections (reviewed by [192]). 
Furthermore, fishes are a major component of the aquatic fauna, and each fish species secretes AMPs with structural differences which can be used by the pharmaceutical industry in its search for novel drugs to treat drug-resistant pathogens. Not only limited to antimicrobial functions, AMPs possess other desirable characteristics which may be exploited in the near future as antimicrobial agents, vaccine adjuvants, inactivated vaccines, and antitumor agents (reviewed by [193]).

3.2.4. Lectins. Hemagglutinins or lectins and lectin-like molecules (the carbohydrate binding proteins of nonimmune origin) have also been found in skin mucus of fishes, and they may participate in innate or acquired immunity (reviewed by [85]). Lectins are elements of the innate immune system which exhibit affinity towards carbohydrate moieties, as well as cell agglutination and/or precipitation of glycoconjugates. For that property they have potential antimicrobial activity in the skin mucus. Lectins interact with pathogenic surface structures that result in opsonisation, enhance phagocytic activity [194], or activation of the complement pathway [195]. Furthermore, agglutinins in fishes are reported to prevent polyspermy [196] and assist in wound healing [60]. It has been demonstrated that lectin levels in fish mucus increase during parasite infection [52].

Among lectins in the skin mucus of fishes, primary structures of four different types of lectin have been determined. Congerin from the conger eel (Conger myriaster) and AJL-1 from the Japanese eel (Anguilla japonica) were identified as galectin, characterized by its specific binding to b-galactoside. Congerins are produced and secreted into mucus by the club cells in the mucosal epithelium lining the skin and digestive tract [197]. In the case of congerins I and II, they can recognize some marine bacteria such as Vibrio anguillarum [198]. Investigation of their localization in fish tissues suggested that they are expressed not only in skin but also in the upper digestive tract and gill filament [198, 199]. Eel has an additional lectin, AJL-2, which has a highly conserved sequence of C-type lectins, but displays Ca2q-independent activity. This is rational because the lectin exerts its function on the cutaneous surface, which is exposed to a Ca2q scarce environment when the eel is in fresh water. Pufflectin is a mannose-specific lectin in the skin mucus of pufferfish. This lectin showed no sequence similarity with any known animal lectins, but surprisingly shares sequence homology with mannose-binding lectins of monocotyledonous plants. Another lectin was found in the ponyfish (Leiognathus nuchalis) and exhibits homology with rhamnose-binding lectins known in eggs of some fish species. These lectins, except ponyfish lectin, showed agglutination of certain bacteria. In addition, pufflectin was found to bind to a parasitic trematode (Heterobothrium okamotoi). Taken together, these results demonstrate that skin mucus lectins in fishes have wide molecular diversity [200]. In another study, a piscine lily-type lectin was described in pufferfish and it was expressed exclusively in mucosal tissues, namely, skin, digestive tract, oral cavity, and gills [201].
A new type of skin mucus lectin was recently found in catfish (Silurus asotus), and it was the first evidence of a fish intelectin protein [202]. Reverse transcription polymerase chain reaction (RT-PCR) demonstrated that the lectin gene was expressed in the skin (as well as in gill and kidney) and more concretely in skin and gill club cells. Although intelectin gene expression was not induced by in vivo bacterial stimulation, the intelectin showed agglutination activity against the pathogenic bacterium Aeromonas salmonicida. All these observations about lectins in fish mucus suggest that they actively participate in the self-defence system by acting on the intra- and extrabody surface.

To date we know only very few functions of lectins, but some results seem to suggest other important roles. For example, although the fundamental galectin function is the specific recognition of glycoconjugates at the molecular level, galectins have been proposed to participate in diverse physiological functions such as development, differentiation, morphogenesis, apoptosis, or metastasis of malignant cells (reviewed by [203, 204]).

3.2.5. Proteins. Several kinds of proteins have been studied in fish mucus, and all of them have important immune functions. For example, lactoferrin is a nonhaem ironbinding protein that is part of the transferrin protein family [205]. In addition to inducing systemic immunity, lactoferrin can promote skin immunity and inhibit allergic responses [206].

The antimicrobial effect of histones has been known for decades $[207,208]$, but only after some years they were linked to the innate immune system of fishes and characterized in different fish species [153,161, 209-213]. Since then, important functions of histones have been described. For example, histone $\mathrm{H} 2 \mathrm{~B}$ was isolated from the skin mucus of Atlantic cod [121] and inhibit important bacterial and fungal pathogens of fishes, for example Aeromonas hydrophila and Saprolegnia spp. [210] being recognized as endogenous antibiotics. Histone fragments with antimicrobial properties have also been isolated and identified in human wound fluid together with alpha-defensins, lysozyme, and LL-37 [214], as well as in fish tissues, where N-terminal segments of catfish $\mathrm{H} 2 \mathrm{~A}$ were shown to be induced in the epidermal mucus upon stimulation $[107,149,153]$. Furthermore, the levels of this histone were suppressed during early stages of stress and reduced in the absence of disease [215].

Unlike histones, many reports describe antimicrobial properties of ribosomal proteins or of fragments thereof. All these data show that ribosomal proteins have a role in immunity, ascribing them to a second function and suggesting also that the ribosomal proteins have multiple functions. An additional antibacterial peptide sharing similarity with the 40 S ribosomal protein S30 was isolated from the skin of the rainbow trout [148], while three 60S ribosomal proteins, L40, L36A, and L35, were identified from the skin of Atlantic cod. Perhaps the most important conclusion is that due to the number of antimicrobial fractions detected, it could be deduced that there are still numerous unidentified antimicrobial components in cod mucus [121]. 
3.2.6. Immunoglobulins. Secretory immunoglobulins (Ig) are produced mainly by plasmablasts and plasma cells and play key roles in the maintenance of mucosal homeostasis. Preparations from mucus from many animal sources have been shown to contain immunoglobulins $[216,217]$. In most major groups of jawed vertebrates, including fishes, the adaptive immune system is based on key molecules such as Ig, T cell receptors (TCR), and the major histocompatibility complex (MHC). It was suggested that, in common with mammalian systems, different immunoglobulins [218] or on the contrary only one [219] may be associated with mucosal immunity in fishes. Until recently, teleost fish B cells were thought to express only two classes of immunoglobulins, IgM and $\operatorname{IgD}[220]$, in which IgM was thought to be the only one responding to pathogens both in systemic and mucosal compartments. However, a third teleost immunoglobulin class, IgT/IgZ, was discovered in 2005, and it has recently been shown to behave as the prevalent immunoglobulin in gut mucosal immune responses (reviewed [10]). Teleost B cells produce three different immunoglobulin isotypes, IgM, IgD, and IgT. While teleost IgM is the principal player in systemic immunity, IgT appears to be a teleost immunoglobulin class specialized in mucosal immune responses [221]. Thus far, three major B cell lineages have been described in teleost, which are those expressing either $\operatorname{IgT}$ or $\operatorname{IgD}$, and the most common lineage which coexpresses IgD and IgM. The evolution of B cells from fishes and mammals have been revised recently [222].

In teleost fishes, IgM molecule is the predominant isotype, consisting of one variable and four constant domains, usually found in plasma, bile and skin mucus [223]. Antibodies in cutaneous mucus and skin of teleosts play a critical role in the protective host defence against surface infections $[224,225]$ and were reported to be similar, but not identical, to serum IgM $[218,226]$. It is thought that the IgM antibodies possess a limited antigen spectrum in fishes. Furthermore, it is very difficult to accurately estimate the concentration of IgM in fish skin mucus because it varies between different individuals. Usually the amounts found are extremely small compared to the amounts of IgA in mammalian secretions and are temperaturedependent. More concretely, IgM levels increase when there is an increase in water temperature [218, 224-227].

Based on several experimental approaches (e.g., serum antibodies given intraperitoneally), it has been probed that IgM molecules are poorly transported to the mucosal secretions. For this reason, it has been proposed that the presence of IgM in skin mucus of fishes is a result of some mechanism mediating its secretion into the external fluids and that cells localised near the skin epithelium are responsible for the production of the cutaneous antibodies (reviewed in [14]). In other words, sIgM is locally produced in the skin and intestine. Curiously, purified IgM from serum was rapidly digested in gut mucus at $4^{\circ} \mathrm{C}$ [228]. Possible involvement of teleost polymeric immunoglobulin receptor (pIgR) in the transport of polymeric IgM to the mucosal epithelia was reported in fugu (Takifugu rubripes), common carp (Cyprinus carpio), and orange-spotted grouper (Epinephelus coioides) $[19,229,230]$. The pIgR plays a pivotal role in mucosal immune protection by transporting secretory immunoglobulins to mucosal epithelia and protecting them from proteolytic degradation. It has been reported that a homolog of the pIgR has a similar role in teleost fishes [99]. While most of the epithelial cells in fugu skin expressed pIgR, other cells such as melanophores did not [229]. IgM producing cells were distributed along the basal membrane of the skin and lamina propria of the intestine [229]. Two pIgR-like cDNAs and genes of Atlantic salmon (Salsal pIgR and Salsal pIgRL) have been studied as well as information of CMRF35-like molecules (CLM) 1, 7, and 8 (designated as CD300 in humans). The abundance of Salsal pIgR transcript is significantly higher than Salsal pIgRL and CLM in the skin, while Salsal pIgRL transcripts were abundant in the gills, depicting their possible tissue-specific role in mucosal immunity [99]. Furthermore, in order to know the roles of these molecules in cutaneous mucosal defence, their transcriptional changes in salmon skin and spleen infected with the ectoparasite Lepeophtheirus salmonis which targets skin and mucus of salmonid fishes were compared. The results corroborate that Salsal pIgR and Salsal pIgRL transcripts significantly increased after fourteen days following infection in both skin and spleen. CLM1 was upregulated only in skin and downregulated in spleen, possibly indicating that CLM1 expressing cells had migrated to the target site [99]. More studies are needed to corroborate this hypothesis and to understand the complicate movements of the immune molecules between the different immune compartments of the fish body.

\section{Fish Skin Mucosal Immunity}

A description of the evolution of the skin-associated immune system from the invertebrates to the vertebrates will be introduced in the present section before referring to the different immune cells present in fish skin. Afterwards, some of the most important aspects about fish mucosal immunity will be underlined.

4.1. Evolution of the Skin-Associated Immune System. The evolution of the skin-associated immune system from the invertebrates to the vertebrates and man has been reviewed by Wölfle et al. [55]. In invertebrates, a nonspecific humoral immune response (including antimicrobial peptides, oxidases, lysozyme, agglutinins, coagulins, and melanin) dominates. The cellular immune system initially consists of undifferentiated mesenchymal stem cells. Later, migrating phagocytes and natural killer cells occur.

Studies on the defence mechanism in the skin surface of agnathans may reveal the origin of mucosal immunity and contribute to studies on the development of mucosal immunology in vertebrates and the evolution of immunity. In contrast to jawed vertebrates, agnathans represented by hagfish and lampreys are athymic and asplenic, but they possess differentiated blood cells including thrombocyte-, granulocyte-, monocyte-, and lymphocyte-like cells [231]. This increasing knowledge regarding the immune components of agnathans has been restricted to systemic immunity. 
Mucosal immunity (including immune system in the skin), which is another important immune system, has not yet been investigated in cyclostomes [232].

The skin of cartilaginous fishes is covered by tooth-like placoid scales that provide firmness and protection. The organized lymphatic tissue of cartilaginous fishes consists of thymus, spleen, and follicle-like collections of lymphocytes in the intestine and blood vessels [233]. Today it is assumed that a (retro)transposon element became inserted in a gene for an immunoglobulin-like protein, allowing the sudden appearance of adaptive immunity [234].

Regarding bony fishes (teleosts) the lymphatic tissue is concentrated around the kidneys. Lymph nodes and bone marrow are not yet present. In the higher bony fish (Teleostei), an adaptive, predominantly humoral immune response is now also found in the skin for the first time. Skin-associated lymphatic follicles are still lacking, but now ATPase-positive dendritic cells and IgMpositive lymphocytes are seen in the epidermis [55]. Allogenic skin grafts are rejected relatively rapidly following a circadian rhythm [235].

In humans, the immune system of the skin (skin immune system (SIS) or skin-associated lymphoid tissue (SALT)) is an independent organ-specific manifestation in contrast to the immune system of other organ systems [236]. Cellular elements of the immune response predominate in the epidermis. While keratinocytes continually wander outwards from the basal layer to the outer border of the organism, epidermal Langerhans cells as the "outermost watchdog of the immune system" hold their suprabasal position, scanning their environment for antigens or danger signals. In the event of danger signals, the dendritic cells of the skin are activated, and they wander out of the epidermis and depart the skin via lymphatics. On their way to the skinassociated lymph nodes, the dendritic cells upregulate their immunocompetence. Presentation of antigen, cell activation and proliferation of antigen-specific lymphocytes occurs mainly in the skin-associated lymph nodes. Immigration of specific and unspecific effector cells into the skin occurs again via the circulatory system and the capillary net of the dermis [237]. While a cellular immune presence dominates in the epidermis and proliferation of immune cells is displaced into deeper compartments, in the intestine that proliferation of immune cells and production of antibodies are directly associated with the epithelium [55]. A more secretory, cellular immune response is seen in the intestine in contrast to the predominantly humoral immune response of the skin [238].

4.2. Immune Cells in Fish Skin. In contrast to mammals, fishes lack major lymphoid accumulations in mucosaassociated tissues [14]. Nevertheless, all MALTs contain a variety of leukocytes, including but not limited to lymphocytes ( $\mathrm{T}$ and $\mathrm{B}$ cells), plasma cells, macrophages, and granulocytes. Little is known about if lymphoid cells can be located in the integument, either naturally or as a result of an immune reaction or inflammation. Leukocytes and probably other ameboid cells can migrate through normal mucus secretions [218, 226, 239-243].
By using ELISPOT it was demonstrated that antibodysecreting cells (ASCs) (including lipopolysaccharide-(LPS-) inducible $\mathrm{B}$ cells, also called plasmablasts, and nonreplicating plasma cells) reside in low numbers in the skin of channel catfish [23]. Moreover, following immunization against the protozoan Ichthyophthirius multifiliis (a parasite which infects skin and gills), the number of ASCs in skin increased 20-fold and remained elevated for at least weeks after the last parasite exposure. The data indicate that the number of ASC in skin is dynamic, responds to the immune status of the fishes, and increases in response to parasite infection. This high number of ASCs in skin serves as the primary source of cutaneous antibodies that confer longterm humoral immunity against reinfection [23]. However, the ontogeny of these cells remains unresolved.

Mast cells, also known as eosinophilic granular cells (EGCs), are present in most species of teleosts and are found in a variety of tissues, including the skin, gut, gills, brain, and in the vicinity of blood vessels [244-248]. Mast cells may play an important role in the mechanisms of inflammatory response because they express a number of functional proteins, including antimicrobial peptides that act against a broad spectrum of pathogens [249-253].

4.3. Fish Skin Mucosal Immunology. Relative to systemic immunity, research into mucosal immunity in teleosts has been scant. However, it is this external division of the immune system that is most susceptible to influence by environmental parameters. This is particularly important in fishes, which are poikilotherms. In fact, the ASCs found in the skin and gills are directly exposed to these extreme conditions, and their function is therefore more likely to be affected [254]. Whilst there have been some studies on immune response in species of interest in aquaculture, very few have considered the effects of the diversity of environmental factors into the fish mucosal immunity. Some of them are now commented. Hyperosmotic pressure has been shown to increase antibody production and gene expression in GS-NS0 cell lines [255]. In a microarray study, more than six hundred genes associated with many cellular processes were upregulated in the cellline, while cell viability was not affected by the stress [255]. This study was conducted on mammalian cell lines. Although it could be thought that a similar phenomenon may occur in cutaneous antibody-secreting cells in fishes under similar hyperosmotic pressure conditions, more studies are needed to clarify this hypothesis. One work carried out on Asian sea bass or barramundi (Lates calcarifer) demonstrated that in this species the cutaneous mucosal antibody response was significantly higher in salt water than in fresh water, and both serum and cutaneous mucosal antibodies were capable of binding antigen at salinities in line with seawater existence. The results demonstrate that this adaptive response could be of great importance to euryhaline fish species that are able to exist and move between vastly diverse physiological environments [254].

Another important factor affecting immune response is the seasonality, although until now there are few studies that 
focus on the relationship between these mucosal immune substances and their seasonal variation. The immune components of olive flounder were studied during different months of the year. The results showed a significant correlation between the mucosal antibodies, hemagglutinating and protease activity, and with the seasonal changes in the water temperature. This reveals a statistically significant inverse relationship between $\mathrm{MuAb}$ (mucosal antibody), hemagglutinin, and proteases in the skin mucus of olive flounder [125]. A positive correlation between water temperature and the level of mucosal antibodies and an inverse relationship between the level of mucosal antibodies and the activity of mucosal hemagglutinin and protease were detected, but no relationship was shown between lysozyme activity and other innate immune substances. This could be part of a compensatory response in order to protect specimens against pathogenic microorganisms which are inherently present in the aquatic environment [125]. Related also to season is aestivation or daily torpor, an adaptive tactic to survive hot and dry periods of low food availability. Aestivation has been documented for species of lungfishes, teleost fishes, and other vertebrates. African lungfishes experience changes in the structure of their skin and gills (besides some more organs) during aestivation [256]. Further studies are needed to understand the changes in the immune system as a result of aestivation.

Susceptibility to different diseases among related species is variable. Research into origins of this variability to assist future disease management is needed because there are only preliminary studies comparing the levels of several important innate humoral parameters found in fish mucus [25]. To date there have been no conclusive results. First studies focused on fish skin mucosal immunity to evaluate the presence or absence of one or more immune activities; then later works focus on the simultaneous evaluation of several of these immunological parameters to determine their potential roles in host resistance [257-259]. At present, works include most relevant immune parameters, or a representative subset, to simultaneously evaluate the quantitative contribution of these immune parameters to host resistance. Most works focus on the mucosal immune response to bacteria and parasites and less on virus infections.

As the first barrier of defence, the skin has an important role in the protection against invasive pathogens. It has long been hypothesized that observed differences in disease susceptibility between species and strains are due to the differing ability of the host to prevent pathogen attachment and entry at mucosal epithelial sites [260-262]. Fishes literally swim in a sea of pathogens, and the importance of mucus in fish defence is now well documented. Thus, any breach in the normal barrier function of the skin can allow colonization of the skin by infectious organisms or invasion by opportunistic microorganisms (microorganisms that normally colonize the skin but are typically of low pathogenicity) $[263,264]$. Some bacteria harvested from a fish skin (e.g., about $50 \%$ and $46.87 \%$ of the $V$. alginolyticus strains harvested from gilthead seabream and sea bass) are able to degrade the skin mucus of the same fish species [265]. This indicates that their presence can make the fishes more susceptible to colonization by pathogenic or opportunistic microorganisms. Furthermore, homeostasis of the physicochemical factors of mucus is very important to avoid the potential invasion and/or adhesion of pathogens to mucosal surfaces, as it has been previously indicated. For example, mucus transport requires wellregulated viscoelasticity which is controlled by hydration. Simply by being slightly more hydrated, the fluid could have a markedly lower viscoelasticity and be readily penetrable by motile bacteria [82]. In fact, in challenge experiments with bacteria, removal of mucus/epidermal cells increased the cumulative mortality in salmonids compared to undamaged fishes [266, 267].

At present, it is well established for many pathogens that the skin and the gills are the point of entry and site of infection. For example, infection by the bacterium Flavobacterium columnare (columnaris disease agent) causes a chronic, ulcerative, necrotic infection of the body surface and gills, often resulting in 100\% mortality over a few days [268], and infection by Ichthyophthirius multifiliis, a protozoan parasite that infects the skin and gills of freshwater fishes, is frequently fatal [224]. Furthermore, a reproducible, experimental model of columnaris disease (a serious condition affecting numerous freshwater fish species all over the world) was developed to study the pathogenesis of cutaneous disease associated with $F$. columnare infection in koi (Cyprinus carpio). After infection, the bacteria were readily detected in skin specimens from infected fishes; however, the bacterium was infrequently detected in liver, kidney, and spleen of affected specimens. These observations suggest that columnaris disease generally presents itself as a cutaneous disease that is unassociated with systemic infection in koi [268]. In other words, different pathogenic microorganisms are able to produce severe alterations to fishes only by affecting the mucosal surface.

It must be taken into account that tissues such as skin and muscle have a limited repertoire of morphological response to injury. The two most important phenomena that determine the outcome of cell injury appear to be critical cell membrane damage (with associated fluid and ionic imbalances) and the inability of mitochondria, the powerhouse of the cell, to restart ATP synthesis. In fishes, cutaneous lesions are generally nonspecific and may be indicative of disease that is restricted to the integument or a manifestation of systemic disease [27]. The skin ulcers can have many different etiologies, including infectious agents, toxins, physical causes, immunologic causes, and nutritional and metabolic perturbations. Ulcerative lesions are likely to be initiated by a series of factors that lead ultimately to a breach of the normal barrier function of the skin (reviewed in [264]). In this sense, the bacteria Moritella viscosa is considered the agent causing winter ulcer diseases characterized by extensive and chronic ulceration of the skin and septicaemia [269-272]. Recently it has been demonstrated that this bacteria (but not A. wodanis) affected or inhibited the epidermal regeneration abilities of keratocytes [273]. To know how to prevent the ulcer apparition in fishes will be very helpful for aquaculture practices in order to prevent opportunistic or pathogenic colonizations. 
Immunoprophylactic control of fish diseases aims at priming the innate and/or the adaptive immune system ahead of infection. Host-bacteria interaction mechanisms include physical bacteria-epithelium interaction (adhesion to mucosal and epithelial cells, stimulation of mucus secretion, production of defensive molecules, reinforcement of gut barrier function), bacteria-immune system interaction (modulation and regulation of immune responses), and also, bacteria-bacteria interaction (exclusion and inhibition of pathogens by prevention of adhesion, secretion of antimicrobial substances, competition of nutrients and antitoxin effects) [274]. The main changes that occur in the integument as a result of an infection include changes in the mucus (either in production rate or composition, nothing is known about whether it changes its microbiota), in the epidermis (inflammatory response and hyperplasia are changes frequently), and the dermis (inflammatory response, ulceration, or dermal lesions caused by parasites) [275]. Of these, the response to certain parasites is the most studied [224]. In the present paper a few examples of bacteria, virus and parasite infections will be now considered.

The mechanisms of pathogenicity induced by certain pathogen bacteria are still uncertain. Vibrio sp. infections are still complex and related to several factors including cytotoxins, enterotoxins, and lytic enzymes [276, 277]. Adhesion ability to human epithelial cell lines (Hep-2 and Caco-2) and fish mucus [278] seem to be diffused among Vibrio alginolyticus strains and may represent a potential infection risk for aquatic stressed animals $[279,280]$. Snoussi et al. [265] confirmed that $V$. alginolyticus strains isolated from a bathing and fishing area (Khenis, Centre of Tunisia) show a specific binding capability to gilthead sea bass and gilthead sea bream mucus. Fouz et al. [281] noted that Photobacterium damselae subsp. damselae strains showed a strong ability to adhere to the fish skin mucus from eel and turbot, exhibiting a degree of adhesion similar to that previously reported for other fish pathogens ( $V$. vulnificus, $V$. alginolyticus, $V$. anguillarum, Aeromonas hydrophila, $P$. damselae subsp. piscicida, and Flexibacter maritimus) for the mucus of different fish species [278, 282, 283]. However, Magarinos et al.[284] demonstrate that the sea bream skin mucus can inhibit the adhesion of Pasteurella piscicida, Flexibacter maritimus, V. anguillarum, and V. damsela.

The available results about the skin mucosal immunity after viral infections are particularly scarce, as was indicated before. It is assumed that capsid viruses must have virtually no hydrophobic patches on their external surfaces large enough to form low affinity bonds with the hydrophobic patches on mucin fibers to diffuse freely through mucus, which is a very good strategy to entry to a fish and cause a disease. Thus, capsid viruses appear well designed to penetrate mucus by being small enough, neutral in net surface charge, and coated densely with charged groups that prevent hydrophobic binding to mucins. Moreover, they have evolved effective methods for adhering selectively to, and entering, their target cells [82]. Future studies will allow an understanding of the relationships between virus and fish mucosa, as well as the mucosal immune response elicited by them.
The skin and gills are common sites of parasite infestation despite the barrier functions associated with mucosal epithelia of fishes. To resist or minimize the impact of parasite infection, both innate and adaptive defence mechanisms have to be involved (reviewed by [285]). Immunity associated with the parasites depends on the inhabiting discrete sites in the host. Especially important for this paper are the ectoparasites, those habiting in or on the skin. Until recently there had been little direct evidence of innate immune mechanisms against parasites associated with mucosal epithelium [285]. The active immunological role of skin against parasitic infection has been shown recently [286-288], and now mucosal immunity against them start to be elucidated. The physicochemical characteristics of skin mucus, the presence of bioactive molecules (lysozyme, complement, C-reactive protein, haemolysins, and lectins) and epidermal migration of inflammatory cells and their secretion may affect the establishment and proliferation of parasites [289].

Mucus, as it has been underlined, plays a role in limiting the parasite load [290]. Monogenean and crustacean ectoparasites modulate mucus production during attachment by reducing the density of mucous cells in the skin of the host [291, 292]. Hypersecretion of mucus [293-297] may be associated [296] or not [298] with a localized epithelial cell hyperplasia. Perhaps the hyperplasia is mediated by IL1 released by activated macrophages [299]. Inflammation is the other cellular process implied in the parasite response in the fish skin.

Controlled challenge trials using naïve animals provide indirect evidence of innate immunity, as well as identifying the host range or specificity of a parasite, often when specific details of defence mechanism(s) are lacking. Two ectoparasitic taxa have contributed to the information about host resistance in fishes: the gyrodactylid monogeneans and the caligid copepods [285]. Monogeneans can be important pathogens of fishes, but their immunological interactions with the host are not well described. Pathogenesis in gyrodactyliasis may be related to skin mucification or to local reduction of mucous cells [300], and on the contrary, mucus turnover may be involved in protecting fishes against invasion [291, 301].

Ichthyophthirius multifiliis is a common obligate, highly motile, free-swimming ectoparasitic pathogen in invertebrates and vertebrates [302, 303], including freshwater fishes $[304,305]$. One of the major clinicopathological manifestations of scuticociliatosis-infected fishes are dark colouration, excessive body mucus, loss of scales, hemorrhagic and/or bleached spots on the skin, and dermal necrotic lesions that finally destroy tissues leading to high mortalities (reviewed by [306]). This parasite feeds on the epithelium of the skin and gills and grows large enough to be visible to the naked eye, impairing gaseous and ionic exchange [307] which subsequently leads to fish death. Non-parasitic fishes usually die following infection, but animals surviving sublethal parasite exposure become resistant to subsequent challenge. This resistance correlates with the presence of humoral antibodies in the sera and cutaneous mucus of immune fishes. This parasite has also been used to study the ontogeny of the 
mucosal immune response [224]. The infection is initiated by invasion of the skin by free swimming, forty millimeter theronts that grow within the epithelium causing extensive damage to the skin. The appearance of serum and cutaneous mucosal antibodies recognizing $i$-antigen correlates with the development of immunity against infection by I. multifiliis. These results suggest that mucosal antibodies are produced locally in skin [287, 308, 309]. In addition, when skin explants from channel catfish immunized against I. multifiliis are cultured in vitro, they release I. multifiliis-specific antibodies, implying that antibodies are actively produced by cells in skin rather than diffusing from serum [310]. Furthermore, vaccination of channel catfish specimens with I. multifiliis leads to the appearance of $\mathrm{i}$-antigen-specific ASC in both skin and serum demonstrating that cutaneous mucosal and systemic immunity are integrated [23].

Tetrahymena corlissi is the agent of "Yet" disease in tropical aquarium fishes and parasitizes skin, muscle, and sometimes invades body cavities of freshwater fishes [311]. The ciliates are characterized by their high potential for systemic invasion, destroying tissues that lead to high mortalities of the host [312]. When the disease manifests, the initial clinical symptoms include loss of scales, hemorrhagic lesion, bleached spots on the skin, and dermal necrotic lesions. Afterwards, some dermal necrotic lesions coalesced to form brownish musky clinical manifestations [313]. In Uronema infection, appearance of brown patches on the skin coincides with the appearance of a large number of pathogens in skin and gill [313]. Other major clinicopathological manifestations include severe necrotic lesions in the epidermal and dermal musculature of posterior half in the affected fishes. The parasite reached the blood stream quickly through the lesions on the skin, and, thus, the ciliates rapidly invade and proliferate in the skin and gills. Afterwards, the parasite consumes both host cells and body fluids and spreads to the internal organs in the absence of any additional pathogens such as secondary bacterial invaders [313]. Recently, the sites of cutaneous mucus antibody induction and the mechanisms by which antibodies are transported to the skin have started to be elucidated [306].

Another important research field at present is to study the effects of the diet on fish mucosal immunity. There are some available results on the increased disease resistance of fishes after dietary administration of some immunostimulants. This underscores the interconnection of mucosal tissues in the body, potentially permitting the application of functional feed additives to improve fish skin health [314]. This is a very new area of interest with a great applicated potential in aquaculture systems. For many fish species, the immune modulation activity of beta-glucans has been reported [315], and recent preliminary research data indicates that beta-glucan promotes an antimicrobial response [316]. Furthermore, beta-glucans can potentially affect mucin structure and/or function as they interact with innate signalling pathways in mucus producing cells. The influence of a dietary beta-glucan immunomodulant on the expression of carp mucin 2 , mucin $5 \mathrm{~B}$, beta-defensin 1 and beta-defensin 2 genes in mucosal tissues (skin, gills, and first and second intestinal segment) has been recently confirmed. Muc5B expression and both beta-defensin genes were significantly increased in the skin. Even though different mucin and defensin genes are expressed in skin and intestine, the regulation of both in the skin of carp after feeding betaglucans suggests that not only the mucosal system of the intestine can be influenced [314]. Comparative studies of different effects of four feed types on white spot disease (caused by Ichthyophthirius multifiliis) susceptibility and skin immune parameters in rainbow trout (Oncorhynchus mykiss) reveal positive effects of beta-glucan. This could be explained as a consequence of the activation of innate immune responses working also at the epidermal level of the fishes [317].

It has also been recently demonstrated that fermented Saccharomyces cerevisiae effectively promotes not only the growth performance, but also the skin nonspecific immune parameters in rainbow trout (namely, lysozyme, protease, hemagglutinin, alkaline phosphatase, and esterase compared to control group). Significant increases were also observed in antibacterial activity against Yersinia ruckeri in fish fed treatment diet [318].

For several years, the use of probiotics has been proposed as a strategy to control bacterial diseases affecting farmed fishes. Probiotics were defined as a live microbial feed supplement which beneficially affects the host animal by improving its microbial balance [319]. This definition is being constantly refined. Probiotics are associated with healthpromoting properties $[320,321]$ and also with other benefits $[322,323]$. However, in aquaculture systems the interaction between the microbiota and the host is not limited to the intestinal tract, and given the nature of fish farming and the fact that water harbours microbial communities, a distinctive definition of probiotic for aquatic animals is accepted [324]. According to these authors "probiotic for aquaculture is a live, dead or component of a microbial cell that, when administered via the feed or to the rearing water, benefits the host by improving either disease resistance, health status, growth performance, feed utilisation, stress response or general vigour, which is achieved at least in part via improving the hosts or the environmental microbial balance." Some criteria such as the adhesion to host surfaces and adhesive interactions with the pathogens may also represent good criteria for the selection of putative probiotics [325-328]. The adhesive competitiveness of different potential probiotic strains (isolated from the microbiota of healthy farmed gilthead seabream included as members of the Vibrionaceae and Pseudomonadaceae and the genus Micrococcus) with the pathogen $V$. harveyi was evaluated [329], and only two isolates (Pdp11, identified as Shewanella putrefaciens, and 51M6) showed an antagonistic effect against $V$. harveyi [329]. Adhesive and antagonistic interactions with $V$. harveyi of some of the isolates assayed may indicate that they could exert an effective biocontrol on the establishment of pathogenic bacteria in farmed sole mucosal surfaces [328]. The first demonstration that probiotics can protect fishes against surface infections was against Aeromonas bestiarum and Ichthyophthirius multifiliis in rainbow trout [330]. The research on this topic is considered of high priority at present 
because enriched diets could be used as preventive or curative therapies for farmed fishes.

\section{Genetic Studies in Fish Skin}

More recent studies in fish skin are focused on genes. The Whole Genome Duplication that happened early in the life of ray-finned fishes is now increasingly believed to have happened about 350 to 450 million year ago and is the main reason for the explosion of the fish species diversity at $>23,500 \mathrm{spp}$. [331]. The gene duplication that happened resulted in the creation of numerous novel or seminovel genes and functions in fishes, known as "more genes in fish than mammals" concept [332]. Genetic diversity translates to protein diversity, and as such it is therefore very possible that in teleost fishes there will be a lot of unique and differing functionalities amidst the background of conserved functions. In fact, many of these fish-specific features are now starting to be unravelled [333].

At present, relatively few teleost genes involved in immune functions have been sequenced, compared to those from higher vertebrates. This limitation significantly affects the application of genomic tools such as microarray technology or real-time quantitative PCR, which provide an integrated overview of the global response at the level of gene expression [334]. While a significant number of genes have been described in immune-related organs, transcriptomic data on peripheral organs barely exist, and the transcriptomic profile of fish skin has been assessed in very few studies [335].

Due to the importance of mucins in mammals, the structure of mucin type genes and their critical role in the infection process in the gastrointestinal tract [336] or in airways [115] have been studied. Based on biochemical characterisation, nineteen genes are currently assigned to the mucin family (see $[337,338]$ ) and are named "MUCnumber" for humans or "Muc-number" for other species [112]. Mucin genes typically possess repetitive region/s which is/are the sites where glycosylation takes place [339]. Five gelforming mucin genes (Muc2, Muc5AC, Muc5B, Muc6, and Muc19) have been described in higher vertebrates [340] and characterization and/or identification of such mucin genes have only been carried out by mucin antibody screening of a cDNA library [341] or bioinformatic means [342]. Mucin genes are yet to be identified in fish skin [314]. Nevertheless, some genes related to the mucus production as well as to other functions also attribute to the skin mucus starting to be studied. For example, the discus fish (Symphysodon aequifasciata) displays extensive parental care behavior through utilization of epidermal mucosal secretion to raise free-swimming fry. Upregulated expression of prolactin receptor (PRLR) mRNA was observed in skin of parental fishes compared to nonparental fishes, indicating possibility of a role of the PRL hormonal signaling in regulation of mucus production in relation to parental care behaviour because prolactin (PRL) has been shown to directly influence parental care- associated behavior in many vertebrate species [93].
In most occasions, genomic studies have permitted ontogenic studies of different humoral immune components present in fish skin mucus, as well as their regulation after different stimulus. This has been the case of some ontogenic studies of complement components of fishes performed on larvae in developmental stages mostly after hatching. Fifty days following hatching, C3 was detected for the first time in myocardial cells of the heart and in columnar epithelial cells of the gut (oesophagus, stomach, and intestine) as well as in epithelial and mucosal cells of the skin [122]. Activation of the complement system, which forms a major part of the innate immune system, results in the formation of the terminal complement complex. The complement component, $\mathrm{C} 7$, plays an integral role in the assembly of this complex within target cell membranes. C7 gene expression was detected in the skin of grass carp (Ctenopharyngodon idella). Furthermore, significant changes in C7 transcript expression ( $>20$-fold) were detected following Aeromonas hydrophila infection, indicating C7 involvement in innate immune responses to bacteria. In fact, C7 is a protein with a putative role in the first line of immune defense [343].

Genetic studies have also permitted the identification of molecules not described by more classical methods, for example, molecules implied in the inflammatory response. No immune-related molecules were identified in the skin of jawless vertebrates until the research carried out by Tsutsui et al. [232] which demonstrated the presence of interleukin (IL)-17, a proinflammatory cytokine, by subtractive hybridization using cultured skin cells of the lamprey (Lethenteron japonicum). This was the first evidence for this cytokine in cyclostomes. IL-17 is one of the key cytokines involved in the mammalian inflammatory response. This molecule stimulates epithelial cells, endothelial fibroblastic cells, and macrophages, resulting in the induction of other inflammatory cytokines such as IL- $1 \beta$, IL-6, IL- 8 , and TNF $\alpha$ [344-346]. The fact that LPS upregulates LampIL-17 expression suggest that LampIL-17 triggers the inflammatory response in the lamprey skin, although many other cytokines may also be involved. The study could then provide the first evidence for the presence of cytokines and a possible cytokine network in the skin of cyclostomes [232].

The expression profiles of some cytokines and their receptors (IL-1 $\beta, \mathrm{IL}-8, \mathrm{TNF} \alpha$, and IL-1-Receptor 1 ) in the skin have also been examined in several fish species, and they are upregulated by infection of mechanical injury to the skin [288, 347-349]. IL-1b gene 1 is significantly expressed in many tissues (liver, head kidney, spleen, intestine, and muscle, but minimally in stomach, brain, and ovary) and skin of pufferfish. IL-1 is an important early response proinflammatory cytokine that mediates immune regulation in both innate and adaptive immunity, and it could be secreted by monocytes, activated macrophages, granulocytes, endothelial cells, activated $\mathrm{T}$ lymphocytes, and many other cell types [350]. Pufferfish IL-15 is constitutively and widely expressed at low levels. Dramatic upregulation of IL-15 could be detected in different tissues after LPS administration and in skin, brain, liver and muscle after stimulation with concanavalin A. The results indicate that IL-15 is biologically relevant to teleost fish adaptive immune response [350]. 
Similarly, in vivo expression analysis of pufferfish IL-21 revealed that IL-21 is only found in gut, gill, and gonad, with higher and wider expression pattern in skin, kidney, spleen, gut, gill, and gonad after LPS treatment. This finding indicates that pufferfish IL-21 is an inflammatory-related gene associated with antibacterial defence [350].

The expression of the proinflammatory cytokines CXCa, CXCb, IL1-beta, anti-inflammatory cytokine IL-10, TNF $\alpha$, and the receptors IL1R1, CXCR1, and CXCR2 in skin of common carp have been studied after mechanical injury. Specific upregulation of the chemokine CXCa, the chemokine receptor CXCR1, and the proinflammatory cytokine IL-beta was detected at $2-3 \mathrm{~h}$ after injury. In order to correlate gene expression patterns after injury with cell migration, chemotaxis of head kidney leukocytes towards lysates of epithelioma papulosum cyprini (EPC) cells was studied, and the results suggest that the increased expression of proinflammatory genes is related to a rapid influx of neutrophilic granulocytes [349].

Skin is considered the largest immunologically active organ, but its molecular mechanism remains unclear in fishes [351]. Different assays have also been developed for the measurement of differential real-time expression of immune-related genes in skin after natural or experimental infections. The results suggest that complicated local signalling networks are present in the fish skin and these networks are involved in the immune response to different microorganisms. Furthermore, in some works the response found in mucus and skin (local immune response) is compared with the immune response in serum (systemic immune response). A few examples are now presented to illustrate different studies carried out in order to elucidate different aspects of immune response against bacteria, virus, and parasites, although these kinds of studies in fishes are still in their infancy.

Invasive pathogenic bacteria use a multitude of different strategies to penetrate host cells and evade killing. While these mechanisms have been the intense focus of microbiologists for decades, only recently have tools been developed to allow the capture of molecular signatures related to host responses and host-pathogen interactions during infection [352]. Using Illumina RNA-seq technology, channel catfish transcriptomic responses in the intestine following challenge with the Gram-negative bacterium Edwardsiella ictaluri have been studied for the first time [352]. The technology has allowed studying a broad representation of catfish genes (including previously unsequenced transcripts) and accurately quantifying transcript levels of 1633 differentially expressed genes.

Two retinoid-related orphan receptor (ROR)-g homologues (ROR-gammaal and -gammaa2) genes are expressed in rainbow trout skin. In vitro studies using trout cell lines demonstrated that ROR-g is induced significantly by LPS and downregulated by the presence of Poly I:C and recombinant interferon (IFN)-g. In vivo studies demonstrated that its expression was significantly higher in vaccinated versus unvaccinated fishes following bacterial (Yersinia ruckeri) challenge, but it was downregulated after a viral (VHSV) infection. All the data suggest a potential role of trout
ROR-g, a putative TH17 transcription factor, in protection against extracellular bacteria [353].

Affymetrix Zebrafish GeneChip was used to assess gene expression in the skin of zebrafish (Danio rerio) infected with the bacterium Citrobacter freundii [351]. The results showed that 229 genes were differentially expressed, of which 196 genes were upregulated and thirty-three genes were downregulated. Ontology and KEGG pathway analyses indicated eighty-eight genes significantly associated with skin immunity involved in complement activation and acute phase response, defense and immune response, response to stress and stimulus, antigen processing and presentation, cell adhesion and migration, platelet activation and coagulation factors, regulation of autophagy and apoptosis. When compared with transcriptional profiles of previously reported carp (Cyprinus carpio) skin, a similar innate immunity (e.g., interferon, lectin, heat shock proteins, complements), and several different acute phase proteins (transferrin, ceruloplasmin, vitellogenin and alpha-1-microglobulin, etc.) were detected in zebrafish skin. The validity of the microarray results was verified by quantitative real-time PCR analysis of nine representative genes. This is first report that skin play important roles in innate immune responses to bacterial infection, which contribute to understanding the defense mechanisms of the fish skin [351].

Some studies focus on the expression of immunerelated genes after experimental infections with parasite. Rainbow trout and Atlantic salmon interleukin-4/13A (IL$4 / 13 \mathrm{~A}$ ) genes were found expressed at high level in skin, in concert with the transcription factor gene GATA-3. And it has been suggested that Th2 skewage may protect fish skin and gill from parasites and from damage by inflammatory Th1 and Th17 responses [354]. Specific gene expression of the proinflammatory cytokine IL-1 and the type II IL1 receptor (IL-1RII, "decoy receptor") was studied also in skin of rainbow trout (Walbaum, 1792) fry during primary and secondary infections with an ectoparasitic monogenean (Gyrodactylus derjavini, Mikailov, 1975). Generally, low levels of specific IL-1_1, IL-1_2, and IL-1RII gene transcription were found in uninfected hosts. In contrast, a clear and strong induction of both IL-1 isoforms could be observed during primary and secondary infections, respectively. This study represented the first example of cytokine expression in fishes induced by an ectoparasitic infection and indicated the importance of localised mucosal immune reactions in responses of fishes towards gyrodactylids [347]. In another work, expression of a number of immune relevant genes (cyto- and chemokines TNF $\alpha 1$, TNF $\alpha 2$, TGF-beta and IL8 , the iNOS and cyclooxygenase (COX-2) genes, and two cell markers, the beta-chains of TCR and MHC II, from the adaptive arm of the immune system, was studied in skin of rainbow trout during both primary and secondary infections with the same parasite. Significant increases in expression of the TNF $\alpha 1$ and TNF $\alpha 2$ isoform were seen while the cytokine TGF-beta increases eight-ten times, in the transcription levels, in secondary infections compared to uninfected hosts. However, no parasite-related changes in expression patterns could be observed for IL-8. Parasite infections elicited strong iNOS expression by four days. 
Augmented expression of COX-2 could also be observed in primary, but not secondary, infections at later stages of infections. No clear parasite-related changes in transcript levels of the two cell markers TCR beta and MHC II beta could be observed. Most of the examined factors appear to take part in a local signalling network of pivotal importance for the initiation, orchestration, effectuation and modulation of immune responses in rainbow trout against this parasite [286].

Cyprinus carpio specimens were infected with the ectoparasite $I$. multifiliis, and the target genes analyzed included the chemokines $\mathrm{CXCa}$ and $\mathrm{CXCb}$, the chemokine receptors CXCR1 and CXCR2, the proinflammatory cytokines IL1beta and TNF $\alpha$ and the enzymes inducible nitric oxide synthase (iNOS) and arginase 2 . The strongest upregulation in skin was observed in the IL-1beta, CXCR1 and iNOS genes at thirty-six-forty-eight hours after exposure to theronts. This study confirms the role of carp skin as an important source of proinflammatory molecules as well as an active modulator of the local inflammation. Cutaneous immune response in $C$. carpio after infection with the ectoparasite $I$. multifiliis was determined by RQ-PCR [348]. A total of 2578 sequences were obtained, and only 1200 clone sequences showed significant similarity to previously reported genes according to the BLASTX sequence alignment. The clones were grouped in seven different categories of the "Biological Process" domain of the Gene Ontology nomenclature [355]: antigen processing and presentation (including MHC I and MHC II, proteasome, several isoforms of beta 2microglobulin), chemotaxis (several chemokines), complement system (factor $\mathrm{P}$ or properdin, a positive regulator of complement activation; factor $\mathrm{D}$ and complement factor 7, C7, an integral component of the lytic pathway of the complement), inflammatory response (prostaglandinD2 synthase; signal transduction (Nuclear factor kappa B (NF$\kappa \mathrm{B})$ and annexin $\mathrm{A} 2$ ), innate immunity (ferritin, scavenge receptors, molecules from the C-type lectin superfamily, interferon (IFN) and two IFN-induced proteins, heat shock or stress proteins (HSPs) [356]. Using the skin libraries and other larger libraries from different tissues [357] a carp cDNA microarray has been designed and printed [356]. The generation of a collection of ESTs clones from carp skin will provide the basis for functional genomics studies in this important organ.

Studies of skin transcriptome and proteome are really scarce in fishes and have only recently begun. There are already five genomic databases sequenced thus far for this taxon: the zebrafish, medaka, stickleback, tiger pufferfish and the green spotted pufferfish (http://www.ensembl.org/), and the whole sequence of the genome of Atlantic salmon is predicted to be made public during the present year 2012 [357]. These are mainly large EST (expressed sequence tag) sequencing projects, aiming to increase the transcriptome coverage [358-361]. The skin transcriptome of fishes is still poorly characterized. Recently the transcriptome of Atlantic salmon has started to be studied, and currently only 2,089 ESTs out of a total of half a million sequences are generated from skin-derived cDNA libraries. Skin is considered to be the largest immunologically active organ, but its molecular mechanism remains unclear in fishes [351]. These studies will enable future gene expression analysis of skin. The relevance of skin as a defensive organ against pathogens and parasites is increased through the identification of several immune relevant genes, both of the innate and adaptive system [362]. In this transcriptome several isotigs exhibiting homology to mammalian mucins (MUC2, MUC5AC and MUC5B) have been identified [362]. Nevertheless, to date, any full-length fish mucin genes has been unearthed, as it was previously indicated.

The skin transcriptome of Atlantic salmon has been studied by using long-read next generation sequencing (NGS), namely, the Roche 454 platform. NGS is revolutionizing the approaches taken to study both transcriptomics and genomics, due to the massive amount of sequence information that can be generated in a relatively short length of time [363]. There are some reports describing NGS on salmonid fish, both wild (Salvelinus namaycush and Coregonus clupeaformis) $[364,365]$ and farmed (S. salar and Oncorhynchus mykiss) [366, 367].

On the other hand, the skin mucosal proteome of Atlantic cod was mapped using a 2D PAGE, LCeMS/MS coupled approach. Mucosal proteins from naive fishes were identified primarily by similarity searches across various cod EST databases. The identified proteins were clustered into eight groups based on gene ontology classification for biological process. Most of the proteins identified from the gel are hitherto unreported for cod. Galectin-1, mannan binding lectin (MBL), serpins, cystatin B, cyclophilin A, FK506 binding protein, proteasome subunits (alpha-3 and -7), ubiquitin, and g-type lysozyme are considered immune competent molecules. Five of the aforementioned proteins were cloned, and their tissue distribution was analysed by RT-PCR [20]. Important advances in fish mucosal immunity will be obtained in the near future by applying omics techniques.

\section{Concluding Remarks and Future Research}

Fishes are the main group of vertebrates and a major component of the aquatic fauna. Evolutionary pressure from pathogens may have led to this divergence in the adaptation of the immune system in different fish species. The functions of immune parameters at the individual, species, and population levels are ambiguous, and the relationships between the various immune parameters remain poorly understood. Increased knowledge of the mucosal innate immune factors could be advantageous in the fish farming and possibly human health, beyond the area of immune evolution.

Skin is considered the largest immunologically active organ, but its molecular mechanism remains unclear in fishes, mainly local signalling network of pivotal importance for the initiation, orchestration, effectuation, and modulation of immune responses [286]. The lower levels of some immune molecules present in skin mucus of some species could possibly be complementing by the involvement of other innate immune mechanisms. The detailed analysis of the innate immune-related molecules fish including their 
function and network will certainly generate new technologies that can be applied to improve aquaculture [333].

The ontogenie, of the cells present in skin and in mucous secretions are unresolved, as well as the importance of the main innate cellular functions of such cells. This would include phagocytosis and especially natural cytotoxic activity. The sites of antigen capture and presentation and the sites of antibody production are still unknown with regard to cutaneous immunity.

Although many genes have started to be studied, the cellular source(s) has not been yet determined. New technologies based on gene study will reveal novel patterns of teleost mucosal gene expression and will highlight unexpected roles for candidate genes and pathways. Utilization of these findings will improve strategies for selection of disease-resistant broodstock and evaluation of prevention and treatment options [352]. Different assays have also been developed for the measurement of differential real-time expression of immune-related genes in skin after natural or experimental infections. The results suggest that complex local signalling networks are present in the fish skin while the pathogen-induced intracellular signalling pathways are still largely undefined. In the same way, many pathogen-regulated genes of interest remain to be identified in the genome of mammals, and there are no available data of the genome of fishes. Identification and characterisation of pathogenregulated genes represent a considerable task to understand the evolution of the infection at the local level and to develop new ways to control these phenomena.

Another important research field at present is to study the effects of the diet on fish mucosal immunity. Probiotics have opened a new era in health management strategy from human to fish, and their use has matured over the years. Probiotics are gaining scientific and commercial interest and are now quite commonplace in health-promoting functional foods to therapeutic, prophylactic, and growth supplements [274]. Since the probiotics have been usually orally administered, the available results on fishes focus on the intestinal immunity. Future research will analyse the effects of oral administration of probiotics at mucosal levels (skin, gills, and gut), taking into account that the mechanisms by which probiotics exert their beneficial effects on the host are largely unknown and new molecular works are needed. This underscores the interconnection of mucosal tissues in the body, potentially permitting the application of functional feed additives to improve fish skin health.

Fish skin mucus has important bactericidal properties, and thus it could be regarded as a potential source of novel antibacterial components of interest in aquaculture practices (as therapeutic agents or as antifouling substances). Furthermore, each fish species secretes AMPs with structural differences which can be used by the pharmaceutical industry in its search for novel drugs to treat drug-resistant pathogens. Furthermore, AMPs possess other desirable characteristics which may be exploited in the near future as antimicrobial agents, vaccine adjuvants, inactivated vaccines, and antitumor agents even for human beings [193].

Because the external epithelial surfaces of fishes are often the points of pathogen entry, a basic understanding of the inductive immune mechanisms and immune cell interactions in the skin and gills is extremely important with regard to new vaccine developments. Insight into the immune effector molecules on mucosals is crucial for the development of new vaccines capable of generating robust immune responses in the mucosa. For that, a deeper knowledge of the mucosal immunity and of the immunological progression from mucosal innate to acquired immune systems is needed in order to prevent and control infectious diseases [22] in fishes.

\section{Acknowledgments}

The financial support of the Spanish Ministry of Science and Innovation under Grant no. AGL-2011-30381-C03-01 and of the Fundación Séneca de la Región de Murcia (Spain) (Grant no. 04538/GERM/06, Grupo de Excelencia de la Región de Murcia) is gratefully acknowledged.

\section{References}

[1] Food and Agriculture Organization of the United Nations, "Aquaculture planning. Policy formulation and implementation of sustainable development," FAO Fisheries and Aquaculture Technical Paper 542, Rome, Italy, 2010.

[2] J. L. Balcázar, I. D. Blas, I. Ruiz-Zarzuela, D. Cunningham, D. Vendrell, and J. L. Múzquiz, "The role of probiotics in aquaculture," Veterinary Microbiology, vol. 114, no. 3-4, pp. 173-186, 2006.

[3] O. L. Akinbowale, H. Peng, and M. D. Barton, "Antimicrobial resistance in bacteria isolated from aquaculture sources in Australia," Journal of Applied Microbiology, vol. 100, no. 5, pp. 1103-1113, 2006.

[4] S. Schwarz and E. Chaslus-Dancla, "Use of antimicrobials in veterinary medicine and mechanisms of resistance," Veterinary Research, vol. 32, no. 3-4, pp. 201-225, 2001.

[5] A. Kesarcodi-Watson, H. Kaspar, M. J. Lategan, and L. Gibson, "Probiotics in aquaculture: the need, principles and mechanisms of action and screening processes," Aquaculture, vol. 274, no. 1, pp. 1-14, 2008.

[6] R. M. Johnson and E. J. Brown, "Cell-mediated immunity in host defense against infectious diseases," in Principles and Practice of Infectious Disease., G. L. Mandell, J. E. Bennett, and R. Dolin, Eds., pp. 131-134, Churchill Livingstone, Philadelphia, Pa, USA, 5th edition, 2000.

[7] C. Maaser and M. F. Kagnoff, "Role of the intestinal epithelium in orchestrating innate and adaptive mucosal immunity," Zeitschrift fur Gastroenterologie, vol. 40, no. 7, pp. 525-529, 2002.

[8] A. E. Ellis, "Innate host defense mechanisms of fish against viruses and bacteria," Developmental and Comparative Immunology, vol. 25, no. 8-9, pp. 827-839, 2001.

[9] S. K. Whyte, "The innate immune response of finfish-a review of current knowledge," Fish and Shellfish Immunology, vol. 23, no. 6, pp. 1127-1151, 2007.

[10] I. Salinas, Y. A. Zhang, and J. O. Sunyer, "Mucosal immunoglobulins and B cells of teleost fish," Developmental and Comparative Immunolology, vol. 35, no. 12, pp. 13461365,2011

[11] B. Fuglem, E. Jirillo, I. Bjerkås et al., "Antigen-sampling cells in the salmonid intestinal epithelium," Developmental and Comparative Immunology, vol. 34, no. 7, pp. 768-774, 2010. 
[12] J. H. W. M. Rombout, L. Abelli, S. Picchietti, G. Scapigliati, and V. Kiron, "Teleost intestinal immunology," Fish and Shellfish Immunology, vol. 31, no. 5, pp. 616-626, 2011.

[13] P. Brandtzaeg, "Basic mechanisms of mucosal immunity-a major adaptive defense system," Immunologist, vol. 3, no. 3, pp. 89-96, 1995.

[14] J. H. W. M. Rombout and E. P. E. M. Joosten, "Immunology of fishes. Mucosal immunity," in Handbook of Vertebrate Immunology, P. P. Pastoret, P. Griebel, H. Bazin, and A. Govaerts, Eds., pp. 39-40, Academic Press, London, UK, 1998.

[15] C. S. Kaetzel, “The polymeric immunoglobulin receptor: bridging innate and adaptive immune responses at mucosal surfaces," Immunological Reviews, vol. 206, pp. 83-99, 2005.

[16] J. M. Woof and J. Mestecky, "Mucosal immunoglobulins," Immunological Reviews, vol. 206, pp. 64-82, 2005.

[17] T. N. McNeilly, S. W. Naylor, A. Mahajan et al., "Escherichia coli O157:H7 colonization in cattle following systemic and mucosal immunization with purified $\mathrm{H} 7$ flagellin," Infection and Immunity, vol. 76, no. 6, pp. 2594-2602, 2008.

[18] K. J. Palaksha, G. W. Shin, Y. R. Kim, and T. S. Jung, "Evaluation of non-specific immune components from the skin mucus of olive flounder (Paralichthys olivaceus)," Fish and Shellfish Immunology, vol. 24, no. 4, pp. 479-488, 2008.

[19] J. H. W. M. Rombout, S. J. L. van der Tuin, G. Yang et al., "Expression of the polymeric Immunoglobulin Receptor (pIgR) in mucosal tissues of common carp (Cyprinus carpio L.)," Fish and Shellfish Immunology, vol. 24, no. 5, pp. 620628, 2008.

[20] B. Rajan, J. M. O. Fernandes, C. M. A. Caipang, V. Kiron, J. H. W. M. Rombout, and M. F. Brinchmann, "Proteome reference map of the skin mucus of Atlantic cod (Gadus morhua) revealing immune competent molecules," Fish and Shellfish Immunology, vol. 31, no. 2, pp. 224-231, 2011.

[21] J. M. Wilson and P. Laurent, "Fish gill morphology: inside out," Journal of Experimental Zoology, vol. 293, no. 3, pp. 192 213, 2002.

[22] P. J. Sansonetti, "To be or not to be a pathogen: that is the mucosally relevant question," Mucosal Immunology, vol. 4, no. 1, pp. 8-14, 2011.

[23] X. Zhao, R. C. Findly, and H. W. Dickerson, "Cutaneous antibody-secreting cells and B cells in a teleost fish," Developmental and Comparative Immunology, vol. 32, no. 5, pp. 500-508, 2008.

[24] A. Kubo, "Dynamic cooperation between epidermal barriers and Langerhans cells," Japanese Journal of Clinical Immunology, vol. 34, no. 2, pp. 76-84, 2011.

[25] M. D. Fast, D. E. Sims, J. F. Burka, A. Mustafa, and N. W. Ross, "Skin morphology and humoral non-specific defence parameters of mucus and plasma in rainbow trout, coho and Atlantic salmon," Comparative Biochemistry and Physiology. A, vol. 132, no. 3, pp. 645-657, 2002.

[26] B. Magnadottir, "Immunological control of fish diseases," Marine Biotechnology, vol. 12, no. 4, pp. 361-379, 2010.

[27] J. M. Groff, "Cutaneous biology and diseases of fish," Veterinary Clinics of North America, vol. 4, no. 2, pp. 321-411, 2001.

[28] A. M. Bullock and R. J. Roberts, "The dermatology of marine teleost fish. I. The normal integument," Oceanography and Marine Biology, vol. 13, pp. 383-411, 1974.

[29] W. S. Marshall and D. Bellamy, "The 50 year evolution of in vitro systems to reveal salt transport functions of teleost fish gills," Comparative Biochemistry and Physiology. A, vol. 155, no. 3, pp. 275-280, 2010.
[30] D. G. Elliott, "Integumentary system," in The Laboratory Fish, G. K. Ostrander, Ed., pp. 271-306, Academic Press, Calif, USA, 1st edition, 2000.

[31] S. Varsamos, C. Nebel, and G. Charmantier, "Ontogeny of osmoregulation in postembryonic fish: a review," Comparative Biochemistry and Physiology A, vol. 141, no. 4, pp. 401429, 2005.

[32] M. Whitear, "The skin surface of bony fishes," Journal of Zoology, vol. 160, no. 4, pp. 437-454, 1970.

[33] M. Whitear, "Secretion in the epidermis of polypteriform fish," Zeitschrift fur Mikroskopisch-Anatomische Forschung, vol. 95, no. 4, pp. 531-543, 1981.

[34] M. Whitear, "The skin of fishes including cyclostomes epidermis," in Biology of the Integument, J. Beireiter-Hahn, A. G. Matolsy, and K. S. Richards, Eds., vol. 2, pp. 8-38, Springer, Berlin, Germany, 1986.

[35] P. Burkhardt-Holm, "Lectin histochemistry of rainbow trout (Oncorhynchus mykiss) gill and skin," Histochemical Journal, vol. 29, no. 11-12, pp. 893-899, 1997.

[36] S. Pinky, S. Mittal, and A. K. Mittal, "Glycoproteins in the epithelium of lips and associated structures of a hill stream fish Garra lamta (Cyprinidae, Cypriniformes): a histochemical investigation," Journal of Veterinary Medicine Series C, vol. 37, no. 2, pp. 101-113, 2008.

[37] M. Pattie Jones, F. G. T. Holliday, and A. E. G. Dunn, “The ultra-structure of the epidermis of larvae of the herring Clupea harengus in relation to the rearing salinity,", Journal of the Marine Biological Association of the United Kindong, vol. 46, no. 2, pp. 235-239, 1966.

[38] R. J. Roberts, M. Bell, and H. Young, "Studies on the skin of plaice (Pleuronectes platessa L.). II. The development of larval plaice skin," Journal of Fish Biology, vol. 5, no. 1, pp. 103-108, 1973.

[39] C. P. O'connell, "Development of organ systems in the northern anchovy, Engraulis mordax, and other teleosts," Integrative and Comparative Biology, vol. 21, no. 2, pp. 429446, 1981.

[40] C. M. Morrison, "Histology of the Atlantic cod Gadhus morhua. An atlas: part 4. Eleutheroembryo and larva," Canadian Special Publication of Fisheries and Aquatic Sciences, vol. 119, pp. 1-504, 1993.

[41] O. H. Ottesen and J. A. Olafsen, "Ontogenetic development and composition of the mucous cells and the occurrence of saccular cells in the epidermis of Atlantic halibut," Journal of Fish Biology, vol. 50, no. 3, pp. 620-633, 1997.

[42] C. Sarasquete, "Histochemical study of skin and gills of Senegal sole, Solea senegalensis larvae and adults," Histology and Histopathology, vol. 13, no. 3, pp. 727-735, 1998.

[43] J. W. Hawkes, "The structure of fish skin. I. General organization," Cell and Tissue Research, vol. 149, no. 2, pp. 147-158, 1974.

[44] G. A. Brown and S. R. Wellings, "Electron microscopy of the skin of the teleost, Hippoglossoides elassodon," Zeitschrift für Zellforschung und Mikroskopische Anatomie, vol. 103, no. 2, pp. 149-169, 1970.

[45] A. K. Mittal and M. Whitear, "Keratinization of fish skin with special reference to the catfish Bagarius bagarius," Cell and Tissue Research, vol. 202, no. 2, pp. 213-230, 1979.

[46] A. S. Romer and T. S. Parsons, The Vertebrate Body, HoltSaunders International, Philadelphia, Pa, USA, 1977.

[47] D. Le Guellec, G. Morvan-Dubois, and J. Y. Sire, "Skin development in bony fish with particular emphasis on 
collagen deposition in the dermis of the zebrafish (Danio rerio)," International Journal of Developmental Biology, vol. 48, no. 2-3, pp. 217-231, 2004.

[48] F. Stellabotte and S. H. Devoto, "The teleost dermomyotome," Developmental Dynamics, vol. 236, no. 9, pp. 2432 2443, 2007.

[49] G. E. Hollway, R. J. Bryson-Richardson, S. Berger, N. J. Cole, T. E. Hall, and P. D. Currie, "Whole-somite rotation generates muscle progenitor cell compartments in the developing zebrafish embryo," Developmental Cell, vol. 12, no. 2, pp. 207-219, 2007.

[50] A. K. Mittal, T. Ueda, O. Fujimori, and K. Yamada, "Histochemical analysls of glycoproteins in the unicellular glands in the epidermis of an Indian freshwater fish Mastacembelus pancalus (Hamilton)," Histochemical Journal, vol. 26, no. 8, pp. 666-677, 1994.

[51] J. E. Harris and S. Hunt, "The fine structure of the epidermis of two species of salmonid fish, the atlantic salmon (Salmo salar L.) and the brown trout (Salmo trutta L.). II. Mucous cells," Cell and Tissue Research, vol. 163, no. 4, pp. 535-543, 1975.

[52] R. H. Easy and N. W. Ross, "Changes in Atlantic salmon (Salmo salar) epidermal mucus protein composition profiles following infection with sea lice (Lepeophtheirus salmonis)," Comparative Biochemistry and Physiology. Part D, vol. 4, no. 3, pp. 159-167, 2009.

[53] S. H. Olafsdottir and K. Buchmann, "Dexamethasone treatment affects skin mucous cell density in Gyrodactylus derjavini infected Salmo salar," Journal of Helminthology, vol. 78, no. 1, pp. 87-90, 2004.

[54] C. Schempp, M. Emde, and U. Wölfle, "Dermatology in the darwin anniversary. Part 1: evolution of the integument," Journal of the German Society of Dermatology, vol. 7, no. 9, pp. 750-758, 2009.

[55] U. Wölfle, S. Martin, M. Emde, and C. Schempp, "Dermatology in the darwin anniversary. Part 2: evolution of the skinassociated immune system," Journal of the German Society of Dermatology, vol. 7, no. 10, pp. 862-870, 2009.

[56] I. N. Vatsos, Y. Kotzamanis, M. Henry, P. Angelidis, and M. Alexis, "Monitoring stress in fish by applying image analysis to their skin mucous cells," European Journal of Histochemistry, vol. 54, no. 2, article e22, 2010.

[57] M. Whitear and A. K. Mittal, "Fine structure of the club cells in the skin of ostariophysan fish," Zeitschrift fur Mikroskopisch-Anatomische Forschung, vol. 97, no. 1, pp. 141157, 1983.

[58] A. M. Cameron and R. Endean, "Epidermal secretions and the evolution of venom glands in fishes," Toxicon, vol. 11, no. 5, pp. 401-410, 1973.

[59] J. M. Al-Hassan, M. Thomson, K. R. Criddle, B. Summers, and R. S. Criddle, "Catfish epidermal secretions in response to threat or injury-a novel defense response," Marine Biology, vol. 88, no. 2, pp. 117-123, 1985.

[60] J. M. Al-Hassan, M. Thomson, and R. S. Criddle, "Accelerated wound healing by a preparation from skin of the Arabian Gulf catfish," Lancet, vol. 1, no. 8332, pp. 1043-1044, 1983.

[61] J. M. Al-Hassan, M. Thomson, M. Ali, and R. S. Criddle, "Toxic and pharmacologically active secretions from the Arabian Gulf catfish (Arius thalassinus, Ruppell)," Toxin Reviews, vol. 6, pp. 1-43, 1987.

[62] J. M. Al-Hassan, M. Thomson, B. Summers, and R. S. Criddle, "Protein composition of the threat induced epidermal secretion from the Arabian Gulf catfish, Arius thalassinus
(Ruppell)," Comparative Biochemistry and Physiology. Part B, vol. 88, no. 3, pp. 813-822, 1987.

[63] J. M. Al-Hassan, M. Dyson, S. R. Young, M. Thomson, and R. S. Criddle, "Acceleration of wound healing responses induced by preparations from the epidermal secretions of the Arabian Gulf catfish (Arius bilineatus, Valenciennes)," Journal of Wilderness Medicine, vol. 2, no. 3, pp. 153-163, 1991.

[64] J. M. Al-Hassan, "Diabetic ulcer healing preparations from the skin of the Arabian Gulf catfish (Arius bilineatus val.): a novel and effective treatment," International Journal of Tissue Reactions, vol. 12, no. 2, pp. 121-135, 1990.

[65] K. L. Shephard, "Functions for fish mucus," Reviews in Fish Biology and Fisheries, vol. 4, no. 4, pp. 401-429, 1994.

[66] P. K. Böckelmann, B. S. Ochandio, and I. J. Bechara, "Histological study of the dynamics in epidermis regeneration of the carp tail fin (Cyprinus carpio, Linnaeus, 1758)," Brazilian Journal of Biology, vol. 70, no. 1, pp. 217-223, 2010.

[67] F. A. Vieira, S. F. Gregorio, S. Ferraresso et al., "Skin healing and scale regeneration in fed and unfed sea bream Sparus auratus," BMC Genomics, vol. 12, article 490, 2011.

[68] Y. Iger, H. A. Jenner, and S. E. Wendelaar Bonga, "Cellular responses in the skin of the trout (Oncorhynchus mykiss) exposed to temperature elevation," Journal of Fish Biology, vol. 44, no. 6, pp. 921-935, 1994.

[69] K. Åsbakk and R. A. Dalmo, "Atlantic salmon (Salmo salar L.) epidermal malpighian cells-motile cells clearing away latex beads in vitro," Journal of Marine Biotechnology, vol. 6, no. 1, pp. 30-34, 1998.

[70] A. K. Mittal and J. S. D. Munshi, "On the regeneration and repair of superficial wounds in the skin of Rita rita (Ham.) (Bagridae, Pisces)," Acta Anatomica, vol. 88, no. 3, pp. 424442, 1974.

[71] I. N. Gostin, A. N. Neagu, and V. Vulpe, "SEM investigations regarding skin micro-morphology and modifications induced by bacterial infections in Cyprinus carpio and Salmo trutta fario," International Journal of Energy and Environment, vol. 5, no. 2, pp. 274-281, 2011.

[72] A. K. Rai, N. Srivastava, A. K. Nigam, U. Kumari, S. Mittal, and A. K. Mittal, "Healing of cutaneous wounds in a freshwater teleost, Labeo rohita: scanning electron microscopical investigation," Microscopy Research and Technique, vol. 75, no. 7, pp. 890-897, 2012.

[73] M. A. Akimenko, M. Marí-Beffa, J. Becerra, and J. Géraudie, "Old questions, new tools, and some answers to the mystery of fin regeneration," Developmental Dynamics, vol. 226, no. 2, pp. 190-201, 2003.

[74] J. L. Fryer and C. N. Lannan, "Three decades of fish cell culture: a current listing of cell lines derived from fishes," Journal of Tissue Culture Methods, vol. 16, no. 2, pp. 87-94, 1994.

[75] W. S. Lakra, T. R. Swaminathan, and K. P. Joy, "Development, characterization, conservation and storage of fish cell lines: a review," Fish Physiology and Biochemistry, vol. 37, no. 1, pp. 1-20, 2011.

[76] D. Barnes, L. Dowell, D. Forest, A. Parton, P. Pavicevic, and S. Kazianis, "Characterization of XM, a novel Xiphophorus melanoma-derived cell line," Zebrafish, vol. 3, no. 3, pp. 371$381,2006$.

[77] S. Rakers, M. Klinger, C. Kruse, and M. Gebert, "Pros and cons of fish skin cells in culture: long-term full skin and short-term scale cell culture from rainbow trout, Oncorhynchus mykiss," European Journal of Cell Biology, vol. 90, no. 12, pp. 1041-1051, 2011. 
[78] K. L. Shephard, "Mucus on the epidermis of fish and its influence on drug delivery," Advanced Drug Delivery Reviews, vol. 11, no. 3, pp. 403-417, 1993.

[79] V. S. Raj, G. Fournier, K. Rakus et al., "Skin mucus of Cyprinus carpio inhibits cyprinid herpesvirus 3 binding to epidermal cells," Veterinary Research, vol. 42, no. 1, p. 92, 2011.

[80] S. Subramanian, S. L. MacKinnon, and N. W. Ross, "A comparative study on innate immune parameters in the epidermal mucus of various fish species," Comparative Biochemistry and Physiology B, vol. 148, no. 3, pp. 256-263, 2007.

[81] S. Subramanian, N. W. Ross, and S. L. MacKinnon, "Comparison of the biochemical composition of normal epidermal mucus and extruded slime of hagfish (Myxine glutinosa L.)," Fish and Shellfish Immunology, vol. 25, no. 5, pp. 625-632, 2008.

[82] R. A. Cone, "Barrier properties of mucus," Advanced Drug Delivery Reviews, vol. 61, no. 2, pp. 75-85, 2009.

[83] L. Mayer, "Mucosal immunity," Pediatrics, vol. 111, no. 6, pp. 1595-1600, 2003.

[84] Y. Nagashima, N. Kikuchi, K. Shimakura, and K. Shiomi, "Purification and characterization of an antibacterial protein in the skin secretion of rockfish Sebastes schlegeli," Comparative Biochemistry and Physiology C, vol. 136, no. 1, pp. 63-71, 2003.

[85] G. A. Ingram, "Substances involved in the natural resistance of fish to infection-a review," Journal of Fish Biology, vol. 16, no. 1, pp. 23-60, 1980.

[86] T. Ogawa, T. Shirai, C. Shionyu-Mitsuyama, T. Yamane, H. Kamiya, and K. Muramoto, "The speciation of conger eel galectins by rapid adaptive evolution," Glycoconjugate Journal, vol. 19, no. 7-9, pp. 451-458, 2004.

[87] V. L. N. Murty, J. Sarosiek, A. Slomiany, and B. L. Slomiany, "Effect of lipids and proteins on the viscosity of gastric mucus glycoprotein," Biochemical and Biophysical Research Communications, vol. 121, no. 2, pp. 521-529, 1984.

[88] D. W. Bechert, M. Bartenwerfer, G. Hoppe, and W. E. Reif, "Drag reduction mechanisms derived from shark skin," in Proccedings of the 15th International Council of Aeronautical Sciences Congress, vol. 2, no. ICAS-86-1.8.3, pp. 1044-1068, London, UK, 1986.

[89] G. Forstner, "Signal transduction, packaging and secretion of mucins," Annual Review of Physiology, vol. 57, pp. 585-605, 1995.

[90] R. C. Boucher, "New concepts of the pathogenesis of cystic fibrosis lung disease," European Respiratory Journal, vol. 23, no. 1, pp. 146-158, 2004.

[91] R. C. Boucher, "Evidence for airway surface dehydration as the initiating event in CF airway disease," Journal of Internal Medicine, vol. 261, no. 1, pp. 5-16, 2007.

[92] R. Tarran, "Regulation of airway surface liquid volume and mucus transport by active ion transport," Proccedings of America Thoracic Society, vol. 1, no. 1, pp. 42-46, 2004.

[93] H. Matsui, M. W. Verghese, M. Kesimer et al., "Reduced three-dimensional motility in dehydrated airway mucus prevents neutrophil capture and killing bacteria on airway epithelial surfaces," Journal of Immunology, vol. 175, no. 2, pp. 1090-1099, 2005.

[94] D. J. Thornton and J. K. Sheehan, "From mucins to mucus: toward a more coherent understanding of this essential barrier," Proccedings of America Thoracic Society, vol. 1, no. 1, pp. 54-61, 2004.
[95] L. Tort, J. C. Balasch, and S. Mackenzie, "Fish immune system. A crossroads between innate and adaptive responses," Inmunologia, vol. 22, no. 3, pp. 277-286, 2003.

[96] T. Yano, "non-specific immune system: humoral defence," in The Fish Immune System: Organism, Pathogen and Environment, G. Iwama and T. Nakanishi, Eds., pp. 105-157, Academic Press, San Diego, Calif, USA.

[97] P. Alvarez-Pellitero, "Fish immunity and parasite infections: from innate immunity to immunoprophylactic prospects," Veterinary Immunology and Immunopathology, vol. 126, no. 3-4, pp. 171-198, 2008.

[98] Z. H. Huang, A. J. Ma, and X. A. Wang, "The immune response of turbot, Scophthalmus maximus (L.), skin to high water temperature," Journal of Fish Diseases, vol. 34, no. 8, pp. 619-627, 2011.

[99] T. M. Tadiso, A. Sharma, and I. Hordvik, "Analysis of polymeric immunoglobulin receptor- and CD300-like molecules from Atlantic salmon," Molecular Immunology, vol. 49, no. 3, pp. 462-473, 2011.

[100] C. Hellio, A. M. Pons, C. Beaupoil, N. Bourgougnon, and Y. L. Gal, "Antibacterial, antifungal and cytotoxic activities of extracts from fish epidermis and epidermal mucus," International Journal of Antimicrobial Agents, vol. 20, no. 3, pp. 214-219, 2002.

[101] H. K. Khong, M. K. Kuah, A. Jaya-Ram, and A. C. ShuChien, "Prolactin receptor mRNA is upregulated in discus fish (Symphysodon aequifasciata) skin during parental phase," Comparative Biochemistry and Physiology. B, vol. 153, no. 1, pp. 18-28, 2009.

[102] C. Kuppulakshmi, M. Prakash, G. Gunasekaran, G. Manimegalai, and S. Sarojini, "Antibacterial properties of fish mucus from Channa punctatus and Cirrhinus mrigala," European Review for Medical and Pharmacological Sciences, vol. 12, no. 3, pp. 149-153, 2008.

[103] Y. Su, "Isolation and identification of pelteobagrin, a novel antimicrobial peptide from the skin mucus of yellow catfish (Pelteobagrus fulvidraco)," Comparative Biochemistry and Physiology. B, vol. 158, no. 2, pp. 149-154, 2011.

[104] O. Y. Wei, R. Xavier, and K. Marimuthu, "Screening of antibacterial activity of mucus extract of snakehead fish, Channa striatus (Bloch)," European Review for Medical and Pharmacological Sciences, vol. 14, no. 8, pp. 675-681, 2010.

[105] V. G. Chinchar, L. Bryan, U. Silphadaung, E. Noga, D. Wade, and L. Rollins-Smith, "Inactivation of viruses infecting ectothermic animals by amphibian and piscine antimicrobial peptides," Virology, vol. 323, no. 2, pp. 268-275, 2004.

[106] F. Aranishi and N. Mano, "Response of skin cathepsins to infection of Edwardsiella tarda in Japanese flounder," Fisheries Science, vol. 66, no. 1, pp. 169-170, 2000.

[107] A. Patrzykat, L. Zhang, V. Mendoza, G. K. Iwama, and R. E. W. Hancock, "Synergy of histone-derived peptides of coho salmon with lysozyme and flounder pleurocidin," Antimicrobial Agents and Chemotherapy, vol. 45, no. 5, pp. 1337-1342, 2001.

[108] N. Blackstock and A. D. Pickering, "Changes in the concentration and histochemistry of epidermal mucous cells during the Alevin and Fry stages of the brown trout Salmo-Trutta," Journal of Zoology, vol. 197, pp. 463-471, 1982.

[109] G. Zaccone, S. Fasulo, A. Licata, and P. Lo Cascio, "Binding of concanavalin A to secretory epidermis in the fish Blennius sanguinolentus pallas: light microscopic and ultrastructural studies," Basic and Applied Histochemistry, vol. 29, no. 2, pp. 135-147, 1985. 
[110] M. Ali, M. Thomson, J. M. Al-Hassan et al., "Comparative biochemical and pharmacological properties of epidermal secretions from Ariid catfish of the Arabian Gulf," Comparative Biochemistry and Physiology. Part B, vol. 92, no. 1, pp. 205-211, 1989.

[111] M. Phillipson, M. E. V. Johansson, J. Henriksnäs et al., “The gastric mucus layers: constituents and regulation of accumulation," American Journal of Physiology. Gastrointestinal and Liver Physiology, vol. 295, no. 4, pp. G806-G812, 2008.

[112] P. Roussel and P. Delmotte, "The diversity of epithelial secreted mucins," Current Organic Chemistry, vol. 8, no. 5, pp. 413-437, 2004.

[113] H. Y. Yan, "A histochemical study on the snout tentacles and snout skin of bristlenose catfish Ancistrus triradiatus," Journal of Fish Biology, vol. 75, no. 4, pp. 845-861, 2009.

[114] M. A. McGuckin, S. K. Lindén, P. Sutton, and T. H. Florin, "Mucin dynamics and enteric pathogens," Nature Reviews Microbiology, vol. 9, no. 4, pp. 265-278, 2011.

[115] D. J. Thornton, K. Rousseau, and M. A. McGuckin, "Structure and function of the polymeric mucins in airways mucus," Annual Review of Physiology, vol. 70, pp. 459-486, 2008.

[116] U. Kumari, M. Yashpal, S. Mittal, and A. K. Mittal, "Histochemical analysis of glycoproteins in the secretory cells in the gill epithelium of a catfish, Rita rita (Siluriformes, Bagridae)," Tissue and Cell, vol. 41, no. 4, pp. 271-280, 2009.

[117] A. Al-Banaw, R. Kenngott, J. M. Al-Hassan, N. Mehana, and F. Sinowatz, "Histochemical analysis of glycoconjugates in the skin of a catfish (Arius tenuispinis, Day)," Journal of Veterinary Medicine. Series C, vol. 39, no. 1, pp. 42-50, 2010.

[118] N. Ebran, S. Julien, N. Orange, B. Auperin, and G. Molle, "Isolation and characterization of novel glycoproteins from fish epidermal mucus: correlation between their pore-forming properties and their antibacterial activities," Biochimica et Biophysica Acta, vol. 1467, no. 2, pp. 271-280, 2000.

[119] A. K. Nigam, U. Kumari, S. Mittal, and A. K. Mittal, "Comparative analysis of innate immune parameters of the skin mucous secretions from certain freshwater teleosts, inhabiting different ecological niches," Fish Physiology and Biochemistry, vol. 38, no. 5, pp. 1245-1256, 2012.

[120] I. Itami, "Defense mechanism of Ayu skin mucus," Journal of the Shimonoseki University Fisheries, vol. 42, pp. 1-71, 1993.

[121] G. Bergsson, B. Agerberth, H. Jörnvall, and G. H. Gudmundsson, "Isolation and identification of antimicrobial components from the epidermal mucus of Atlantic cod (Gadus morhua)," FEBS Journal, vol. 272, no. 19, pp. 49604969, 2005.

[122] B. Magnadottir, S. Lange, S. Gudmundsdottir, J. Bøgwald, and R. A. Dalmo, "Ontogeny of humoral immune parameters in fish," Fish and Shellfish Immunology, vol. 19, no. 5, pp. 429439, 2005.

[123] A. E. Ellis, "Immunity to bacteria in fish," Fish and Shellfish Immunology, vol. 9, no. 4, pp. 291-308, 1999.

[124] S. Saurabh and P. K. Sahoo, "Lysozyme: an important defence molecule of fish innate immune system," Aquaculture Research, vol. 39, no. 3, pp. 223-239, 2008.

[125] T. S. Jung, C. S. del Castillo, P. K. Javaregowda et al., "Seasonal variation and comparative analysis of non-specific humoral immune substances in the skin mucus of olive flounder (Paralichthys olivaceus)," , Developmental and Comparative Immunology, vol. 38, no. 2, pp. 295-301, 2012.

[126] A. K. Rai and A. K. Mittal, "Histochemical response of alkaline phosphatase activity during the healing of cutaneous wounds in a cat-fish," Experientia, vol. 39, no. 5, pp. 520-522, 1983.

[127] A. K. Rai and A. K. Mittal, "On the activity of acid phosphatise during skin regeneration in Heteropneustes fossilis," Bulletin of Life Sciences, vol. 1, pp. 33-39, 1991.

[128] Y. Iger and M. Abraham, "The process of skin healing in experimentally wounded carp," Journal of Fish Biolology, vol. 36, pp. 421-437, 1990.

[129] N. W. Ross, K. J. Firth, A. Wang, J. F. Burka, and S. C. Johnson, "Changes in hydrolytic enzyme activities of naive Atlantic salmon Salmo salar skin mucus due to infection with the salmon louse Lepeophtheirus salmonis and cortisol implantation," Diseases of Aquatic Organisms, vol. 41, no. 1, pp. 43-51, 2000.

[130] Y. Iger and M. Abraham, "Rodlet cells in the epidermis of fish exposed to stressors," Tissue and Cell, vol. 29, no. 4, pp. 431438, 1997.

[131] F. Aranishi, "Purification and characterization of $\alpha 1$ proteinase inhibitor from carp (Cyprinus carpio) serum," Marine Biotechnology, vol. 1, no. 1, pp. 33-43, 1999.

[132] J. H. Cho, I. Y. Park, M. S. Kim, and S. C. Kim, "Matrix metalloproteinase 2 is involved in the regulation of the antimicrobial peptide parasin I production in catfish skin mucosa," FEBS Letters, vol. 531, no. 3, pp. 459-463, 2002.

[133] T. Nakano, "Unique molecular properties of superoxide dismutase from teleost fish skin," FEBS Letters, vol. 360, no. 2, pp. 197-201, 1995.

[134] M. A. Bordas, M. C. Balebona, I. Zorrilla, J. J. Borrego, and M. A. Moriñigo, "Kinetics of adhesion of selected fish-pathogenic Vibrio strains to skin mucus of gilt-head sea bream (Sparus aurata L.)," Applied and Environmental Microbiology, vol. 62, no. 10, pp. 3650-3654, 1996.

[135] B. S. Hartley, "Proteolytic enzymes," Annual Review of Biochemistry, vol. 29, pp. 45-72, 1960.

[136] M. Nonaka and S. Miyazawa, "Evolution of the initiating enzymes of the complement system," Genome Biology, vol. 3, no. 1, article no. 1001, pp. 1001.1-1001.5, 2002.

[137] K. Hjelmeland, M. Christie, and J. Raa, "Skin mucus protease from rainbow-trout, Salmo gairdneri Richardson, and its biological significance," Journal of Fish Biology, vol. 23, no. 1, pp. 13-22, 1983.

[138] F. Aranishi and M. Nakane, "Epidermal proteases of the Japanese eel," Fish Physiology and Biochemistry, vol. 16, no. 6, pp. 471-478, 1997.

[139] K. J. Firth, S. C. Johnson, and N. W. Ross, "Characterization of proteases in the skin mucus of Atlantic salmon (Salmo salar) infected with the salmon louse (Lepeophtheirus salmonis) and in whole-body louse homogenate," Journal of Parasitology, vol. 86, no. 6, pp. 1199-1205, 2000.

[140] J. H. Cho, I. Y. Park, H. S. Kim, W. T. Lee, M. S. Kim, and S. C. Kim, "Cathepsin D produces antimicrobial peptide parasin I from histone $\mathrm{H} 2 \mathrm{~A}$ in the skin mucosa of fish," The FASEB Journal, vol. 16, no. 3, pp. 429-431, 2002.

[141] C. M. C. Salles, S. G. De-Simone, S. A. T. Leitão et al., "Identification and characterization of proteases from skin mucus of tambacu, a Neotropical hybrid fish," Fish Physiology and Biochemistry, vol. 33, no. 2, pp. 173-179, 2007.

[142] F. Aranishi, N. Mano, and H. Hirose, "Fluorescence localization of epidermal cathepsins L and B in the Japanese eel," Fish Physiology and Biochemistry, vol. 19, no. 3, pp. 205-209, 1998.

[143] J. H. Morrissey, "Coagulation factor VIIa," in Handbook of Proteolytic Enzymes, A. J. Barret, N. D. Rawlings, and J. F. Woessner, Eds., pp. 161-163, Academic Press, London, UK, 1998. 
[144] J. M. O. Fernandes, G. Molle, G. D. Kemp, and V. J. Smith, "Isolation and characterisation of oncorhyncin II, a histone H1-derived antimicrobial peptide from skin secretions of rainbow trout, Oncorhynchus mykiss," Developmental and Comparative Immunology, vol. 28, no. 2, pp. 127-138, 2004.

[145] J. Kennedy, P. Baker, C. Piper et al., "Isolation and analysis of bacteria with antimicrobial activities from the marine sponge haliclona simulans collected from irish waters," Marine Biotechnology, vol. 11, no. 3, pp. 384-396, 2009.

[146] A. Patrzykat, C. L. Friedrich, L. Zhang, V. Mendoza, and R. E. W. Hancock, "Sublethal concentrations of pleurocidin-derived antimicrobial peptides inhibit macromolecular synthesis in Escherichia coli," Antimicrobial Agents and Chemotherapy, vol. 46, no. 3, pp. 605-614, 2002.

[147] A. M. Cole, P. Weis, and G. Diamond, "Isolation and characterization of pleurocidin, an antimicrobial peptide in the skin secretions of winter flounder," Journal of Biological Chemistry, vol. 272, no. 18, pp. 12008-12013, 1997.

[148] J. M. O. Fernandes and V. J. Smith, "A novel antimicrobial function for a ribosomal peptide from rainbow trout skin," Biochemical and Biophysical Research Communications, vol. 296, no. 1, pp. 167-171, 2002.

[149] G. A. Birkemo, T. Lüders, Ø. Andersen, I. F. Nes, and J. Nissen-Meyer, "Hipposin, a histone-derived antimicrobial peptide in Atlantic halibut (Hippoglossus hippoglossus L.)," Biochimica et Biophysica Acta, vol. 1646, no. 1-2, pp. 207-215, 2003.

[150] J. Ruangsri, J. M. O. Fernandes, M. Brinchmann, and V. Kiron, "Antimicrobial activity in the tissues of Atlantic cod (Gadus morhua L.)," Fish and Shellfish Immunology, vol. 28, no. 5-6, pp. 879-886, 2010.

[151] U. Silphaduang and E. J. Noga, "Peptide antibiotics in mast cells of fish," Nature, vol. 414, no. 6861, pp. 268-269, 2001.

[152] H. M. Murray, J. W. Gallant, and S. E. Douglas, "Cellular localization of pleurocidin gene expression and synthesis in winter flounder gill using immunohistochemistry and in situ hybridization," Cell and Tissue Research, vol. 312, no. 2, pp. 197-202, 2003.

[153] I. Y. Park, C. B. Park, M. S. Kim, and S. C. Kim, "Parasin $\mathrm{I}$, an antimicrobial peptide derived from histone $\mathrm{H} 2 \mathrm{~A}$ in the catfish, ParaSilurus asotus," FEBS Letters, vol. 437, no. 3, pp. 258-262, 1998.

[154] A. Sarmaşik, "Antimicrobial peptides: a potential therapeutic alternative for the treatment of fish diseases," Turkish Journal of Biology, vol. 26, no. 4, pp. 201-207, 2002.

[155] J. Wiesner and A. Vilcinskas, "Antimicrobial peptides: the ancient arm of the human immune system," Virulence, vol. 1, no. 5, pp. 440-464, 2010.

[156] S. Subramanian, N. W. Ross, and S. L. MacKinnon, "Myxinidin, a novel antimicrobial peptide from the epidermal mucus of hagfish, Myxine glutinosa L," Marine Biotechnology, vol. 11, no. 6, pp. 748-757, 2009.

[157] U. Silphaduang, A. Colorni, and E. J. Noga, "Evidence for widespread distribution of piscidin antimicrobial peptides in teleost fish," Diseases of Aquatic Organisms, vol. 72, no. 3, pp. 241-252, 2006.

[158] L. Najafian and A. S. Babji, "A review of fish-derived antioxidant and antimicrobial peptides: their production, assessment, and applications," Peptides, vol. 33, no. 1, pp. 178-185, 2012.

[159] V. J. Smith and J. M. O. Fernandes, "Non-specific antimicrobial proteins of the innate system," in Fish Defences, G. Zaccone, J. Meseguer, A. García-Ayala, and B. G. Kapoor,
Eds., vol. 1, pp. 241-275, Science Publishers, Enfield, NH, USA, 2009.

[160] S. A. Thompson, K. Tachibana, K. Nakanishi, and I. Kubota, "Melittin-like peptides from the shark-repelling defense secretion of the sole pardachirus pavoninus," Science, vol. 233, no. 4761, pp. 341-343, 1986.

[161] J. M. O. Fernandes, N. Saint, G. D. Kemp, and V. J. Smith, "Oncorhyncin III: a potent antimicrobial peptide derived from the non-histone chromosomal protein $\mathrm{H} 6$ of rainbow trout, Oncorhynchus mykiss," Biochemical Journal, vol. 373, no. 2, pp. 621-628, 2003.

[162] T. Lüders, G. A. Birkemo, J. Nissen-Meyer, Ø. Andersen, and I. F. Nes, "Proline conformation-dependent antimicrobial activity of a proline-rich histone $\mathrm{H} 1 \mathrm{~N}$-terminal peptide fragment isolated from the skin mucus of Atlantic salmon," Antimicrobial Agents and Chemotherapy, vol. 49, no. 6, pp. 2399-2406, 2005.

[163] I. Mulero, E. J. Noga, J. Meseguer, A. García-Ayala, and V. Mulero, "The antimicrobial peptides piscidins are stored in the granules of professional phagocytic granulocytes of fish and are delivered to the bacteria-containing phagosome upon phagocytosis," Developmental and Comparative Immunology, vol. 32, no. 12, pp. 1531-1538, 2008.

[164] J. M. O. Fernandes, J. Ruangsri, and V. Kiron, "Atlantic cod piscidin and its diversification through positive selection," PLoS One, vol. 5, no. 3, Article ID e9501, 2010.

[165] G. Salerno, N. Parrinello, P. Roch, and M. Cammarata, "cDNA sequence and tissue expression of an antimicrobial peptide, dicentracin; a new component of the moronecidin family isolated from head kidney leukocytes of sea bass, Dicentrarchus labrax," Comparative Biochemistry and Physiology B, vol. 146, no. 4, pp. 521-529, 2007.

[166] N. Iijima, N. Tanimoto, Y. Emoto et al., "Purification and characterization of three isoforms of chrysophsin, a novel antimicrobial peptide in the gills of the red sea bream, Chrysophrys major," European Journal of Biochemistry, vol. 270, no. 4, pp. 675-686, 2003.

[167] Z. X. Yin, W. He, W. J. Chen et al., "Cloning, expression and antimicrobial activity of an antimicrobial peptide, epinecidin-1, from the orange-spotted grouper, Epinephelus coioides," Aquaculture, vol. 253, no. 1-4, pp. 204-211, 2006.

[168] S. A. Lee, Y. K. Kim, S. S. Lim et al., "Solution structure and cell selectivity of piscidin 1 and its analogues," Biochemistry, vol. 46, no. 12, pp. 3653-3663, 2007.

[169] W. S. Sung, J. Lee, and D. G. Lee, "Fungicidal effect and the mode of action of piscidin 2 derived from hybrid striped bass," Biochemical and Biophysical Research Communications, vol. 371, no. 3, pp. 551-555, 2008.

[170] S. Campagna, N. Saint, G. Molle, and A. Aumelas, "Structure and mechanism of action of the antimicrobial peptide piscidin," Biochemistry, vol. 46, no. 7, pp. 1771-1778, 2007.

[171] X. Lauth, H. Shike, J. C. Burns et al., "Discovery and characterization of two isoforms of moronecidin, a novel antimicrobial peptide from hybrid striped bass," Journal of Biological Chemistry, vol. 277, no. 7, pp. 5030-5039, 2002.

[172] E. J. Noga, U. Silphaduang, N. G. Park, J. K. Seo, J. Stephenson, and S. Kozlowicz, "Piscidin 4, a novel member of the piscidin family of antimicrobial peptides," Comparative Biochemistry and Physiology. B, vol. 152, no. 4, pp. 299-305, 2009.

[173] E. J. Noga and U. Silphaduang, "Piscidins: a novel family of peptide antibiotics from fish," Drug News and Perspectives, vol. 16, no. 2, pp. 87-92, 2003. 
[174] C. I. Chang, Y. A. Zhang, J. Zou, P. Nie, and C. J. Secombes, "Two cathelicidin genes are present in both rainbow trout (Oncorhynchus mykiss) and atlantic salmon (Salmo salar)," Antimicrobial Agents and Chemotherapy, vol. 50, no. 1, pp. 185-195, 2006.

[175] V. H. Maier, K. V. Dorn, B. K. Gudmundsdottir, and G. H. Gudmundsson, "Characterisation of cathelicidin gene family members in divergent fish species," Molecular Immunology, vol. 45, no. 14, pp. 3723-3730, 2008.

[176] T. Uzzell, E. D. Stolzenberg, A. E. Shinnar, and M. Zasloff, "Hagfish intestinal antimicrobial peptides are ancient cathelicidins," Peptides, vol. 24, no. 11, pp. 1655-1667, 2003.

[177] K. Matsuzaki, K. I. Sugishita, and K. Miyajima, "Interactions of an antimicrobial peptide, magainin 2, with lipopolysaccharide-containing liposomes as a model for outer membranes of Gram-negative bacteria," FEBS Letters, vol. 449, no. 2-3, pp. 221-224, 1999.

[178] Y. Shai, "Mechanism of the binding, insertion and destabilization of phospholipid bilayer membranes by $\alpha$-helical antimicrobial and cell non-selective membrane-lytic peptides," Biochimica et Biophysica Acta, vol. 1462, no. 1-2, pp. 55-70, 1999.

[179] J. Zou, C. Mercier, A. Koussounadis, and C. Secombes, "Discovery of multiple beta-defensin like homologues in teleost fish," Molecular Immunology, vol. 44, no. 4, pp. 638647, 2007.

[180] E. Casadei, T. Wang, J. Zou, J. L. González Vecino, S. Wadsworth, and C. J. Secombes, "Characterization of three novel $\beta$-defensin antimicrobial peptides in rainbow trout (Oncorhynchus mykiss)," Molecular Immunology, vol. 46, no. 16, pp. 3358-3366, 2009.

[181] J. G. Zhao, L. Zhou, J. Y. Jin et al., "Antimicrobial activityspecific to Gram-negative bacteria and immune modulationmediated NF- $\kappa$ B and Sp1 of a medaka $\beta$-defensin," Developmental and Comparative Immunology, vol. 33, no. 4, pp. 624637, 2009.

[182] A. Falco, V. Chico, L. Marroquí, L. Perez, J. M. Coll, and A. Estepa, "Expression and antiviral activity of a $\beta$-defensinlike peptide identified in the rainbow trout (Oncorhynchus mykiss) EST sequences," Molecular Immunology, vol. 45, no. 3, pp. 757-765, 2008.

[183] B. H. Nam, J. Y. Moon, Y. O. Kim et al., "Multiple $\beta$-defensin isoforms identified in early developmental stages of the teleost Paralichthys olivaceus," Fish and Shellfish Immunology, vol. 28, no. 2, pp. 267-274, 2010.

[184] C. H. Park, E. V. Valore, A. J. Waring, and T. Ganz, "Hepcidin, a rinary antimicrobial peptide synthesized in the liver," Journal of Biological Chemistry, vol. 276, no. 11, pp. 78067810, 2001.

[185] D. M. E. Bowdish, D. J. Davidson, and R. E. W. Hancock, "A re-evaluation of the role of host defence peptides in mammalian immunity," Current Protein and Peptide Science, vol. 6, no. 1, pp. 35-51, 2005.

[186] E. J. Noga, P. J. Borron, J. Hinshaw, W. C. Gordon, L. J. Gordon, and J. K. Seo, "Identification of histones as endogenous antibiotics in fish and quantification in rainbow trout (Oncorhynchus mykiss) skin and gill," Fish Physiology and Biochemistry, vol. 37, no. 1, pp. 135-152, 2011.

[187] A. J. Ullal, R. Wayne Litaker, and E. J. Noga, "Antimicrobial peptides derived from hemoglobin are expressed in epithelium of channel catfish (Ictalurus punctatus, Rafinesque)," Developmental and Comparative Immunology, vol. 32, no. 11, pp. 1301-1312, 2008.
[188] A. J. Ullal and E. J. Noga, "Antiparasitic activity of the antimicrobial peptide $\mathrm{Hb} \beta \mathrm{P}-1$, a member of the $\beta$-haemoglobin peptide family," Journal of Fish Diseases, vol. 33, no. 8, pp. 657-664, 2010.

[189] E. Zahran, J. K. Seo, and E. J. Noga, “The effect of adjuvant and microbial challenge on the expression of antimicrobial polypeptides in channel catfish (Ictalurus punctatus)," Fish and Shellfish Immunology, vol. 33, no. 2, pp. 168-173, 2012.

[190] M. Guebre-Xabier, S. A. Hammond, L. R. Ellingsworth, and G. M. Glenn, "Immunostimulant patch enhances immune responses to influenza virus vaccine in aged mice," Journal of Virology, vol. 78, no. 14, pp. 7610-7618, 2004.

[191] M. Cumberbatch, M. Bhushan, R. J. Dearman, I. Kimber, and C. E. M. Griffiths, 'IL- $1 \beta$-induced Langerhans' cell migration and TNF- $\alpha$ production in human skin: regulation by lactoferrin," Clinical and Experimental Immunology, vol. 132, no. 2, pp. 352-359, 2003.

[192] A. Falco, M. Ortega-Villaizan, V. Chico et al., "Antimicrobial peptides as model molecules for the development of novel antiviral agents in aquaculture," Mini-Reviews in Medicinal Chemistry, vol. 9, no. 10, pp. 1159-1164, 2009.

[193] V. Rajanbabu and J. Y. Chen, "Applications of antimicrobial peptides from fish and perspectives for the future," Peptides, vol. 32, no. 2, pp. 415-420, 2011.

[194] C. A. Ottinger, S. C. Johnson, K. V. Ewart, L. L. Brown, and N. W. Ross, "Enhancement of anti-Aeromonas salmonicida activity in Atlantic salmon (Salmo salar) macrophages by a mannose-binding lectin," Comparative Biochemistry and Physiology C, vol. 123, no. 1, pp. 53-59, 1999.

[195] M. Matsushita, A. Matsushita, Y. Endo et al., "Origin of the classical complement pathway: lamprey orthologue of mammalian C1q acts as a lectin," Proceedings of the National Academy of Sciences of the United States of America, vol. 101, no. 27, pp. 10127-10131, 2004.

[196] J. Nosek, A. Krajhanzl, and J. Kocourek, "Studies on lectins. LVII. Immunofluorescence localization of lectins present in fish ovaries," Histochemistry, vol. 79, no. 1, pp. 131-139, 1983.

[197] O. Nakamura, T. Watanabe, H. Kamiya, and K. Muramoto, "Galectin containing cells in the skin and mucosal tissues in Japanese conger eel, Conger myriaster: an immunohistochemical study," Developmental and Comparative Immunology, vol. 25, no. 5-6, pp. 431-437, 2001.

[198] H. Kamiya, K. Muramoto, and R. Goto, "Purification and properties of agglutinins from conger eel, Conger myriaster (Brevoort), skin mucus," Developmental and Comparative Immunology, vol. 12, no. 2, pp. 309-318, 1988.

[199] T. Ogawa, C. Ishii, D. Kagawa, K. Muramoto, and H. Kamiya, "Accelerated evolution in the protein-coding region of galectin cDNAs, congerin I and congerin II, from skin mucus of conger eel (Conger myriaster)," Bioscience, Biotechnology and Biochemistry, vol. 63, no. 7, pp. 1203-1208, 1999.

[200] Y. Suzuki, S. Tasumi, S. Tsutsui, M. Okamoto, and H. Suetake, "Molecular diversity of skin mucus lectins in fish," Comparative Biochemistry and Physiology. B, vol. 136, no. 4, pp. 723-730, 2003.

[201] S. Tsutsui, S. Tasumi, H. Suetake, and Y. Suzuki, "Lectins homologous to those of monocotyledonous plants in the skin mucus and intestine of pufferfish, Fugu rubripes," Journal of Biological Chemistry, vol. 278, no. 23, pp. 20882-20889, 2003.

[202] S. Tsutsui, Y. Komatsu, T. Sugiura, K. Arabi, and O. Nakamura, "A unique epidermal mucus lectin identified from catfish (Silurus asotus): first evidence of intelectin in fish skin 
slime," Journal of Biochemistry, vol. 150, no. 5, pp. 501-514, 2011.

[203] K. I. Kasai and J. Hirabayashi, "Galectins: a family of animal lectins that decipher glycocodes," Journal of Biochemistry, vol. 119, no. 1, pp. 1-8, 1996.

[204] G. A. Rabinovich and N. Rubinstein, "Galectins: a novel family of proteins involved in the regulation of the immune response. Implications in immunopathological processes," Medicina, vol. 61, no. 1, pp. 85-92, 2001.

[205] F. L. Schanbacher, R. E. Goodman, and R. S. Talhouk, "Bovine mammary lactoferrin: implications from messenger ribonucleic acid (mRNA) sequence and regulation contrary to other milk proteins," Journal of Dairy Science, vol. 76, no. 12, pp. 3812-3831, 1992.

[206] S. A. González-Chávez, S. Arévalo-Gallegos, and Q. RascónCruz, "Lactoferrin: structure, function and applications," International Journal of Antimicrobial Agents, vol. 33, no. 4, pp. 301.e1-301.e8, 2009.

[207] T. H. Thatcher and M. A. Gorovsky, "Phylogenetic analysis of the core histones H2A, H2B, H3, and H4," Nucleic Acids Research, vol. 22, no. 2, pp. 174-179, 1994.

[208] S. De Falco, G. Russo, A. Angiolillo, and C. Pietropaolo, "Human L7a ribosomal protein: sequence, stuctural organization, and expression of a functional gene," Gene, vol. 126, no. 2, pp. 227-235, 1993.

[209] A. Kootstra and G. S. Bailey, "Primary structure of histone H2B from trout (Salmo trutta) testes," Biochemistry, vol. 17, no. 13, pp. 2504-2510, 1978.

[210] D. Robinette, S. Wada, T. Arroll, M. G. Levy, W. L. Miller, and E. J. Noga, "Antimicrobial activity in the skin of the channel catfish Ictalurus punctatus: characterization of broadspectrum histone-like antimicrobial proteins," Cellular and Molecular Life Sciences, vol. 54, no. 5, pp. 467-475, 1998.

[211] E. J. Noga, Z. Fan, and U. Silphaduang, "Histone-like proteins from fish are lethal to the parasitic dinoflagellate Amyloodinium ocellatum," Parasitology, vol. 123, no. 1, pp. 57-65, 2001.

[212] R. C. Richards, D. B. O’Neil, P. Thibault, and K. V. Ewart, "Histone H1: an antimicrobial protein of Atlantic salmon (Salmo salar)," Biochemical and Biophysical Research Communications, vol. 284, no. 3, pp. 549-555, 2001.

[213] J. M. O. Fernandes, G. D. Kemp, G. G. Molle, and V. J. Smith, "Anti-microbial properties of histone H2A from skin secretions of rainbow trout, Oncorhynchus mykiss," Biochemical Journal, vol. 368, no. 2, pp. 611-620, 2002.

[214] M. Frohm, H. Gunne, A. C. Bergman et al., "Biochemical and antibacterial analysis of human wound and blister fluid," European Journal of Biochemistry, vol. 237, no. 1, pp. 86-92, 1996.

[215] D. W. Robinette and E. J. Noga, "Histone-like protein: a novel method for measuring stress in fish," Diseases of Aquatic Organisms, vol. 44, no. 2, pp. 97-107, 2001.

[216] J. E. Harris and S. Hunt, "The fine structure of iridophores in the skin of the Atlantic salmon (Salmo salar L.)," Tissue and Cell, vol. 5, no. 3, pp. 479-488, 1973.

[217] W. Pigman, "Mucus glycoprotein," in The Glycoconjugates, M. I. Horowitz and W. Pigman, Eds., vol. 1, pp. 131-137, Academic Press, New York, NY, USA, 1977.

[218] J. H. W. M. Rombout, N. Taverne, M. Van de Kamp, and A. J. Taverne-Thiele, "Differences in mucus and serum immunoglobulin of carp (Cyprinus carpio L.)," Developmental and Comparative Immunology, vol. 17, no. 4, pp. 309-317, 1993.
[219] N. R. Saha, H. Suetake, and Y. Suzuki, "Characterization and expression of the immunoglobulin light chain in the fugu: evidence of a solitaire type," Immunogenetics, vol. 56, no. 1, pp. 47-55, 2004.

[220] I. Hordvik, J. Thevarajan, I. Samdal, N. Bastani, and B. Krossøy, "Molecular cloning and phylogenetic analysis of the Atlantic salmon immunoglobulin D gene," Scandinavian Journal of Immunology, vol. 50, no. 2, pp. 202-210, 1999.

[221] Y. A. Zhang, I. Salinas, J. Li et al., "IgT, a primitive immunoglobulin class specialized in mucosal immunity," Nature Immunology, vol. 11, no. 9, pp. 827-835, 2010.

[222] J. O. Sunyer, "Evolutionary and functional relationships of B cells from fish and mammals: insights into their novel roles in phagocytosis and presentation of particulate antigen," Infectious Disorders Drug Targets, vol. 12, no. 3, pp. 200-212, 2012.

[223] M. F. Flajnik, K. Miller, and L. Du Pasquier, "Evolution of the Immune System," in Fundamental Immunology, W. E. Paul, Ed., pp. 519-570, Lippincott Williams \& Wilkins, Philadelphia, Pa, USA, 5th edition, 2003.

[224] H. Dickerson and T. Clark, "Ichthyophthirius multifiliis: a model of cutaneous infection and immunity in fishes," Immunological Reviews, vol. 166, pp. 377-384, 1998.

[225] T. G. Clark, T. L. Lin, and H. W. Dickerson, "Surface antigen cross-linking triggers forced exit of a protozoan parasite from its host," Proceedings of the National Academy of Sciences of the United States of America, vol. 93, no. 13, pp. 6825-6829, 1996.

[226] C. J. Lobb and L. W. Clem, "Phylogeny of immunoglobulin structure and function. XI. Secretory immunoglobulins in the cutaneous mucus of the sheepshead, Archosargus probatocephalus," Developmental and Comparative Immunology, vol. 5, no. 4, pp. 587-596, 1981.

[227] T. L. Lin, T. G. Clark, and H. Dickerson, "Passive immunization of channel catfish (Ictalurus punctatus) against the ciliated protozoan parasite Ichthyophthirius multifiliis by use of murine monoclonal antibodies," Infection and Immunity, vol. 64, no. 10, pp. 4085-4090, 1996.

[228] F. Hatten, Å. Fredriksen, I. Hordvik, and C. Endresen, "Presence of IgM in cutaneous mucus, but not in gut mucus of Atlantic salmon, Salmo salar. Serum IgM is rapidly degraded when added to gut mucus," Fish and Shellfish Immunology, vol. 11, no. 3, pp. 257-268, 2001.

[229] K. Hamuro, H. Suetake, N. R. Saha, K. Kikuchi, and Y. Suzuki, "A teleost polymeric Ig receptor exhibiting two Ig-like domains transports tetrameric IgM into the skin," Journal of Immunology, vol. 178, no. 9, pp. 5682-5689, 2007.

[230] L. N. Feng, D. Q. Lu, J. X. Bei et al., "Molecular cloning and functional analysis of polymeric immunoglobulin receptor gene in orange-spotted grouper (Epinephelus coioides)," Comparative Biochemistry and Physiology. B, vol. 154, no. 3, pp. 282-289, 2009.

[231] I. C. Potter, L. R. Percy, D. L. Barber, and D. J. Macey, "The morphology, development and physiology of blood cells," in The Biology of Lampreys, M. V. Hardisty and I. C. Potter, Eds., vol. 2, pp. 233-289, Academic, London, UK, 1972.

[232] S. Tsutsui, O. Nakamura, and T. Watanabe, "Lamprey (Lethenteron japonicum) IL-17 upregulated by LPSstimulation in the skin cells," Immunogenetics, vol. 59, no. 11, pp. 873-882, 2007.

[233] E. L. Cooper, A. Pérez, and A. Castell, "Comparative immunology of the integument," in Skin Immune System, J. D. Bos, Ed., pp. 19-53, CRC Press, Boca Raton, Fla, USA, 2005. 
[234] A. Agrawal, Q. M. Eastmant, and D. G. Schatz, "Transposition mediated by RAG-1 and RAG2 and its implications for the evolution of the immune system," Nature, vol. 394, no. 6695, pp. 744-751, 1998.

[235] M. F. Flajnik and L. Du Pasquier, "Evolution of innate and adaptive immunity: can we draw a line?" Trends in Immunology, vol. 25, no. 12, pp. 640-644, 2004.

[236] T. S. Kupper and R. C. Fuhlbrigge, "Immune surveillance in the skin: mechanisms and clinical consequences," Nature Reviews Immunology, vol. 4, no. 3, pp. 211-222, 2004.

[237] J. D. Bos, Skin Immune System. Cutaneous Immunology and Clinical Immunodermatology, CRC Press, Boca Raton, Fla, USA, 2005.

[238] G. A. Holländer, Immunologie. Grundlagen Für Klinik und Praxis, Elsevier, München, Germany, 2006.

[239] C. J. Lobb, "Secretory immunity induced in catfish, Ictalurus punctatus, following bath immunization," Developmental and Comparative Immunology, vol. 11, no. 4, pp. 727-738, 1987.

[240] T. Itami, Y. Takahashi, T. Oamoto, and K. Kubono, "Purification and characterization of immunoglobulin in skin mucus and serum of ayu," Nippon Suisan Gakkaishi, vol. 54, pp. 1611-1617, 1988.

[241] A. H. Al-Harbi and B. Austin, "Purification of macroglobulins from the serum, and skin and gut mucus of turbot (Scophthalmus maximus L.) immunized with lipopolysaccaride (LPS) from a fish-pathogenic Cytophaga-like bacterium (CLB)," Bulletin of the European Association of Fish Pathologists, vol. 13, pp. 40-44, 1993.

[242] S. Ferri, "Electron microscopic study of lymphocytes in a freshwater teleost (Pimelodus maculatus) epidermis," Anatomischer Anzeiger, vol. 154, no. 2, pp. 161-168, 1983.

[243] M. R. Parkhurst and W. M. Saltzman, "Leukocytes migrate through three-dimensional gels of midcycle cervical mucus," Cellular Immunology, vol. 156, no. 1, pp. 77-94, 1994.

[244] D. N. Ezeasor and W. M. Stokoe, "A cytochemical, light and electron microscopic study of the eosinophilic granule cells in the gut of the rainbow trout, Salmo gairdneri Richardson," Journal of Fish Biology, vol. 17, no. 6, pp. 619-634, 1980.

[245] A. E. Ellis, "Eosinophilic granular cells (EGC) and histamine responses to Aeromonas salmonicida toxins in rainbow trout," Developmental and Comparative Immunology, vol. 9, no. 2, pp. 251-260, 1985.

[246] O. B. Reite, "Mast cells/eosinophilic granule cells of salmonids: staining properties and responses to noxious agents," Fish and Shellfish Immunology, vol. 7, no. 8, pp. 567-584, 1997.

[247] A. F. Mazon, M. O. Huising, A. J. Taverne-Thiele, J. Bastiaans, and B. M. L. Verburg-van Kemenade, "The first appearance of Rodlet cells in carp (Cyprinus carpio L.) ontogeny and their possible roles during stress and parasite infection," Fish and Shellfish Immunology, vol. 22, no. 1, pp. 27-37, 2007.

[248] H. M. Murray, C. T. Leggiadro, and S. E. Douglas, "Immunocytochemical localization of pleurocidin to the cytoplasmic granules of eosinophilic granular cells from the winter flounder gill," Journal of Fish Biology, vol. 70, supplement C, pp. 336-345, 2007.

[249] R. Reimschuessel, R. O. Bennett, E. B. May, and M. M. Lipsky, "Eosinophilic granular cell response to a microsporidian infection in a sergeant major fish Abudefduf saxatilis L," Journal of Fish Diseases, vol. 10, pp. 319-322, 1987.

[250] G. J. E. Sharp, A. W. Pike, and C. J. Secombes, "The immune response of wild rainbow trout, Salmo gairdneri Richardson, to naturally acquired plerocercoid infections of Diphyllobothrium dendriticum (Nitzsch, 1824) and
D. ditremum (Creplin, 1825)," Journal of Fish Biology, vol. 35, no. 6, pp. 781-794, 1989.

[251] B. S. Dezfuli, G. Giovinazzo, A. Lui, and L. Giari, "Inflammatory response to Dentitruncus truttae (Acanthocephala) in the intestine of brown trout," Fish and Shellfish Immunology, vol. 24, no. 6, pp. 726-733, 2008.

[252] B. S. Dezfuli, M. Manera, and L. Giari, "Immune response to nematode larvae in the liver and pancreas of minnow, Phoxinus phoxinus (L.)," Journal of Fish Diseases, vol. 32, no. 4, pp. 383-390, 2009.

[253] E. R. Lauriano, M. Calò, G. Silvestri, D. Zaccone, S. Pergolizzi, and P. Lo Cascio, "Mast cells in the intestine and gills of the sea bream, Sparus aurata, exposed to a polychlorinated biphenyl, PCB 126," Acta Histochemica, no. 2, pp. 166-171, 2012.

[254] J. Delamare-Deboutteville, D. Wood, and A. C. Barnes, "Response and function of cutaneous mucosal and serum antibodies in barramundi (Lates calcarifer) acclimated in seawater and freshwater," Fish and Shellfish Immunology, vol. 21, no. 1, pp. 92-101, 2006.

[255] M. H. Wu, G. Dimopoulos, A. Mantalaris, and J. Varley, "The effect of hyperosmotic pressure on antibody production and gene expression in the GS-NS0 cell line," Biotechnology and Applied Biochemistry, vol. 40, no. 1, pp. 41-46, 2004.

[256] S. M. Secor and J. H. Lignot, "Morphological plasticity of vertebrate aestivation," Progress in molecular and subcellular biology, vol. 49, pp. 183-208, 2010.

[257] C. J. Secombes, "The non-specific immune system: cellular defenses," in The Fish Immune System. Organism, Pathogen, and Environment, G. Iwama and T. Nakanishi, Eds., pp. 63103, Academic Press, Sydney, Australia, 1996.

[258] B. Köllner and G. Kotterba, "Temperature dependent activation of leucocyte populations of rainbow trout, Oncorhynchus mykiss, after intraperitoneal immunisation with Aeromonas salmonicida," Fish and Shellfish Immunology, vol. 12, no. 1, pp. 35-48, 2002.

[259] B. Köllner, B. Wasserrab, G. Kotterba, and U. Fischer, "Evaluation of immune functions of rainbow trout (Oncorhynchus mykiss) - how can environmental influences be detected?" Toxicology Letters, vol. 131, no. 1-2, pp. 83-95, 2002.

[260] J. A. Plumb and J. Chappell, "Susceptibility of blue catfish to channel catfish virus," in Proccedings of the Annual Conference of Southeast Assocication of Fish and Wildl Agents, vol. 32, pp. 680-685, 1978.

[261] D. D. Ourth and K. T. Chung, "Purification of antimicrobial factor from granules of channel catfish peripheral blood leucocytes," Biochemical and Biophysical Research Communications, vol. 313, no. 1, pp. 28-36, 2004.

[262] B. R. Griffin and A. J. Mitchell, "Susceptibility of channel catfish, Ictalurus punctatus (Rafinesque), to Edwardsiella ictaluri challenge following copper sulphate exposure," Journal of Fish Diseases, vol. 30, no. 10, pp. 581-585, 2007.

[263] R. Cone, "Mucus," in Mucosal Immunology, P. L. Ogra, J. Mestecky, M. E. Lamm, W. Strober, J. Bienestock, and J. R. McGhee, Eds., pp. 43-64, Academic Press, London, UK, 1999.

[264] M. Law, "Differential diagnosis of ulcerative lesions in fish," Environmental Health Perspectives, vol. 109, no. 5, pp. 681686, 2001.

[265] M. Snoussi, E. Noumi, J. Cheriaa et al., "Adhesive properties of environmental Vibrio alginolyticus strains to biotic and abiotic surfaces," New Microbiologica, vol. 31, no. 4, pp. 489$500,2008$. 
[266] J. Madetoja, P. Nyman, and T. Wiklund, "Flavobacterium psychrophilum, invasion into and shedding by rainbow trout Oncorhynchus mykiss," Diseases of Aquatic Organisms, vol. 43, no. 1, pp. 27-38, 2000.

[267] J. Madetoja, I. Dalsgaard, and T. Wiklund, "Occurrence of Flavobacterium psychrophilum in fish-farming environments," Diseases of Aquatic Organisms, vol. 52, no. 2, pp. 109$118,2002$.

[268] N. K. Tripathi, K. S. Latimer, C. R. Gregory, B. W. Ritchie, R. E. Wooley, and R. L. Walker, "Development and evaluation of an experimental model of cutaneous columnaris disease in koi Cyprinus carpio," Journal of Veterinary Diagnostic Investigation, vol. 17, no. 1, pp. 45-54, 2005.

[269] M. Løvoll, C. R. Wiik-Nielsen, H. S. Tunsjø et al., "Atlantic salmon bath challenged with Moritella viscosa-pathogen invasion and host response," Fish and Shellfish Immunology, vol. 26, no. 6, pp. 877-884, 2009.

[270] H. C. Ingerslev, T. Lunder, and M. E. Nielsen, "Inflammatory and regenerative responses in salmonids following mechanical tissue damage and natural infection," Fish and Shellfish Immunology, vol. 29, no. 3, pp. 440-450, 2010.

[271] B. Bjornsdottir, T. Gudmundsdottir, and B. K. Gudmundsdottir, "Virulence properties of Moritella viscosa extracellular products," Journal of Fish Diseases, vol. 34, no. 5, pp. 333-343, 2011.

[272] B. K. Gudmundsdóttir, B. Björnsdóttir, S. Gudmundsdóttir, and S. H. Bambir, "A comparative study of susceptibility and induced pathology of cod, Gadus morhua (L.), and halibut, Hippoglossus hippoglossus (L.), following experimental infection with Moritella viscosa," Journal of Fish Diseases, vol. 29, no. 8, pp. 481-487, 2006.

[273] C. Karlsen, H. Sørum, N. P. Willassen, and K. A. Sbakk, "Moritella viscosa bypasses Atlantic salmon epidermal keratocyte clearing activity and might use skin surfaces as a port of infection," Veterinary Microbiology, vol. 154, no. 3-4, pp. 353-362, 2012.

[274] S. Salminen, S. Nybom, J. Meriluoto, M. C. Collado, S. Vesterlund, and H. El-Nezami, "Interaction of probiotics and pathogens-benefits to human health?" Current Opinion in Biotechnology, vol. 21, no. 2, pp. 157-167, 2010.

[275] X. Y. Li, S. H. Zeng, W. H. Zhang, L. Liu, S. Ma, and J. J. Wang, "Acute toxicity and superficial damage to goldfish from the ionic liquid 1-methyl-3-octylimidazolium bromide," Environmental Toxicology, vol. 13, no. 4, 2011.

[276] W. Baffone, B. Citterio, E. Vittoria et al., "Determination of several potential virulence factors in Vibrio spp. isolated from sea water," Food Microbiology, vol. 18, no. 5, pp. 479-488, 2001.

[277] S. Zanetti, A. Deriu, L. Volterra et al., "Virulence factors in Vibrio alginolyticus strains isolated from aquatic environments," Annali di Igiene, vol. 12, no. 6, pp. 487-491, 2000.

[278] M. C. Balebona, M. A. Moriñigo, A. Faris et al., "Influence of salinity and $\mathrm{pH}$ on the adhesion of pathogenic Vibrio strains to Sparus aurata skin mucus," Aquaculture, vol. 132, no. 1-2, pp. 113-120, 1995.

[279] I. Zorrilla, M. A. Moriñigo, D. Castro, M. C. Balebona, and J. J. Borrego, "Intraspecific characterization of Vibrio alginolyticus isolates recovered from cultured fish in Spain," Journal of Applied Microbiology, vol. 95, no. 5, pp. 1106-1116, 2003.

[280] W. Baffone, R. Tarsi, L. Pane et al., "Detection of freeliving and plankton-bound vibrios in coastal waters of the Adriatic Sea (Italy) and study of their pathogenicityassociated properties," Environmental Microbiology, vol. 8, no. 7, pp. 1299-1305, 2006.

[281] B. Fouz, A. E. Toranzo, M. Milan, and C. Amaro, "Evidence that water transmits the disease caused by the fish pathogen Photobacterium damselae subsp. damselae," Journal of Applied Microbiology, vol. 88, no. 3, pp. 531-535, 2000.

[282] K. Krovacek, A. Faris, W. Ahne, and I. Mansson, "Adhesion of Aeromonas hydrophila and Vibrio anguillarum to fish cells and to mucus-coated glass slides," FEMS Microbiology Letters, vol. 42, no. 1, pp. 85-89, 1987.

[283] C. Amaro, E. G. Biosca, B. Fouz, E. Alcaide, and C. Esteve, "Evidence that water transmits Vibrio vulnificus biotype 2 infections to eels," Applied and Environmental Microbiology, vol. 61, no. 3, pp. 1133-1137, 1995.

[284] B. Magarinos, F. Pazos, Y. Santos, J. L. Romalde, and A. E. Toranzo, "Response of Pasteurella piscicida and Flexibacter maritimus to skin mucus of marine fish," Diseases of Aquatic Organisms, vol. 21, no. 2, pp. 103-108, 1995.

[285] S. R. M. Jones, "The occurrence and mechanisms of innate immunity against parasites in fish," Developmental and Comparative Immunology, vol. 25, no. 8-9, pp. 841-852, 2001.

[286] T. Lindenstrøm, C. J. Secombes, and K. Buchmann, "Expression of immune response genes in rainbow trout skin induced by Gyrodactylus derjavini infections," Veterinary Immunology and Immunopathology, vol. 97, no. 3-4, pp. 137148, 2004.

[287] J. Sigh, T. Lindenstrøm, and K. Buchmann, "Expression of pro-inflammatory cytokines in rainbow trout (Oncorhynchus mykiss) during an infection with Ichthyophthirius multifiliis," Fish and Shellfish Immunology, vol. 17, no. 1, pp. 75-86, 2004.

[288] J. Sigh, T. Lindenstrom, and K. Buchmann, "The parasitic ciliate Ichthyophthirius multifiliis induces expression of immune relevant genes in rainbow trout, Oncorhynchus mykiss (Walbaum)," Journal of Fish Diseases, vol. 27, no. 7, pp. 409-417, 2004.

[289] P. W. Kania, O. Evensen, T. B. Larsen, and K. Buchmann, "Molecular and immunohistochemical studies on epidermal responses in Atlantic salmon Salmo salar L. induced by Gyrodactylus salaris Malmberg, 1957," Journal of Helminthology, vol. 84, no. 2, pp. 166-172, 2010.

[290] K. Buchmann, "Microenvironment of Gyrodactylus derjavini on rainbow trout Oncorhynchus mykiss: association between mucous cell density in skin and site selection," Parasitology Research, vol. 84, no. 1, pp. 17-24, 1997.

[291] P. R. Wells and D. K. Cone, "Experimental studies on the effect of Gyrodactylus colemanensis and G. salmonis on density of mucous cells in the epidermis of fry of Oncorhynchus mykiss," Journal of Fish Biology, vol. 37, pp. 599-603, 1990.

[292] D. T. Nolan, P. Reilly, and S. E. Wendelaar Bonga, "Infection with low numbers of the sea louse Lepeophtheirus salmonis induces stress-related effects in postsmolt Atlantic salmon (Salmo salar)," Canadian Journal of Fisheries and Aquatic Sciences, vol. 56, no. 6, pp. 947-959, 1999.

[293] M. Prost, "Investigations on the development and pathogenicity of Dactylogyrus anchoratus (Duj, 1845) and D. extensus Mueller and v. Cleave, 1952 for breeding carps," Acta Parasitologica Polonica, vol. 11, pp. 17-47, 1963.

[294] B. Chan and B. Wu, "Studies on the pathogenicity, biology and treatment of Pseudodactylogyrus for the eels in fish farms," Acta Zoologica Sinica, vol. 30, pp. 173-180, 1984. 
[295] R. S. Hines and D. T. Spira, "Ichthyophthiriasis in the mirror carp. II. Leukocyte response," Journal of Fish Biology, vol. 6, no. 4, pp. 527-534, 1973.

[296] M. T. Ventura and I. Paperna, "Histopathology of Ichthyophthirius multifiliis infections in fishes," Journal of Fish Biology, vol. 27, no. 2, pp. 185-203, 1985.

[297] R. J. G. Lester and F. R. Roubal, "Phylum arthropoda," in Fish Diseases and Disorders, Volume 1 Protozoan and Metazoan Infections, P. T. K. Woo, Ed., pp. 475-598, CAB InternationalOxon, Wallingford, UK, 1995.

[298] I. Paperna, "Competitive exclusion of Dactylogyrus extensus by Dactylogyrus vastator (Trematoda, Monogenea) on the gills of reared carp," in Journal of Parasitology, vol. 50, pp. 9498, 1964.

[299] K. Buchmann and J. Bresciani, "Rainbow trout leucocyte activity: influence on the ectoparasitic monogenean Gyrodactylus derjavini," Diseases of Aquatic Organisms, vol. 35, no. 1, pp. 13-22, 1999.

[300] M. E. Scott and M. A. Robinson, "Challenge infections of Gyrodacfylus bullatarudis (Monogenea) on guppies, Poccilia reticulata (Peters), following treatment," in Journal of Fish Biology, vol. 24, pp. 581-586, 1984.

[301] R. J. G. Lester and J. R. Adams, "A simple model of a Gyrodactylus population," International Journal for Parasitology, vol. 4, no. 5, pp. 497-506, 1974.

[302] R. A. Matthews, "Ichthyophthirius multifiliis Fouquet, 1876: infection and protective response within the fish host," in Parasitic Diseases of Fish, A. W. Pike and J. W. Lewis, Eds., pp. 17-42, Samara, Russia, 1st edition.

[303] N. D. Levine, J. O. Corliss, F. E. Cox et al., "A newly revised classification of the protozoa," Journal of Protozoology, vol. 27, no. 1, pp. 37-58, 1980.

[304] R. F. Nigrelli, K. S. Pokorny, and G. D. Ruggieri, "Notes on Ichthyophthirius multifilis, a ciliate parasitic on fresh-water fishes, with some remarks on possible physiological races and species," Transactions of the American Microscopical Society, vol. 95, no. 4, pp. 607-613, 1976.

[305] R. A. Matthews, "Ichthyophthirius multifiliis fouquet and ichthyophthiriosis in freshwater teleosts," Advances in Parasitology, vol. 59, pp. 159-241, 2005.

[306] R. Harikrishnan, C. Balasundaram, and M. S. Heo, "Scuticociliatosis and its recent prophylactic measures in aquaculture with special reference to South Korea. Taxonomy, diversity and diagnosis of scuticociliatosis: part I. Control strategies of scuticociliatosis: Part II," Fish and Shellfish Immunology, vol. 29, no. 1, pp. 15-31, 2010.

[307] M. S. Ewing, M. C. Black, V. S. Blazer, and K. M. Kocan, "Plasma chloride and gill epithelial response of channel catfish to infection with Ichthyophthirius multifiliis," Journal of Aquatic Animal Health, vol. 6, no. 3, pp. 187-196, 1994.

[308] M. B. Schrøder, E. Flaño, L. Pilström, and T. O. Jorgensen, "Localisation of Ig heavy chain mRNA positive cells in Atlantic cod (Gadus morhua L.) tissues; Identified by in situ hybridisation," Fish and Shellfish Immunology, vol. 8, no. 8, pp. 565-576, 1998.

[309] R. N. Grøntvedt and S. Espelid, "Immunoglobulin producing cells in the spotted wolffish (Anarhichas minor Olafsen): localization in adults and during juvenile development," Developmental and Comparative Immunology, vol. 27, no. 67, pp. 569-578, 2003.

[310] D. H. Xu, P. H. Klesius, and R. A. Shelby, "Cutaneous antibodies in excised skin from channel catfish, Ictalurus punctatus Rafinesque, immune to Ichthyophthirius multifiliis," Journal of Fish Diseases, vol. 25, no. 1, pp. 45-52, 2002.
[311] J. Lom, "Trichodinidae and other ciliates (Phylum Ciliophora)," in Fish Diseases and Disorders. Volume 1, Protozoan and Metazoan Infections, P. T. K. Woo, Ed., pp. 229-262, CAB, 1995.

[312] M. K. Sung, B. C. Jae, K. K. Sung, K. N. Yoon, and H. K. Ki, "Occurrence of scuticociliatosis in olive flounder Paralichthys olivaceus by Phiasterides dicentrarchi (Ciliophora: Scuticociliatida)," Diseases of Aquatic Organisms, vol. 62, no. 3, pp. 233238, 2004.

[313] I. S. Azad, A. Al-Marzouk, C. M. James, S. Almatar, and H. Al-Gharabally, "Scuticociliatosis-associated mortalities and histopathology of natural infection in cultured silver pomfret (Pampus argenteus Euphrasen) in Kuwait," Aquaculture, vol. 262, no. 2-4, pp. 202-210, 2007.

[314] M. Van der Marel, M. Adamek, S. F. Gonzalez et al., "Molecular cloning and expression of two b-defensin and two mucin genes in common carp (Cyprinus carpio L.) and their up-regulation after b-glucan feeding," Fish and Shellfish Immunology, vol. 32, no. 3, pp. 494-501, 2012.

[315] A. Figueras, M. M. Santarem, and B. Novoa, "Influence of the sequence of administration of $\beta$-glucans and a Vibrio damsela vaccine on the immune response of turbot (Scophthalmus maximus L.)," Veterinary Immunology and Immunopathology, vol. 64, no. 1, pp. 59-68, 1998.

[316] I. J. Thompson, P. C. F. Oyston, and D. E. Williamson, "Potential of the $\beta$-glucans to enhance innate resistance to biological agents," Expert Review of Anti-Infective Therapy, vol. 8, no. 3, pp. 339-352, 2010.

[317] J. Xueqin, P. W. Kania, and K. Buchmann, "Comparative effects of four feed types on white spot disease susceptibility and skin immune parameters in rainbow trout, Oncorhynchus mykiss (Walbaum)," Journal of Fish Diseases, vol. 35, no. 2, pp. 127-135, 2012.

[318] N. Sheikhzadeh, M. Heidarieh, A. K. Pashaki, K. Nofouzi, M. A. Farshbafi, and M. Akbari, "Hilyse, fermented Saccharomyces cerevisiae, enhances the growth performance and skin non-specific immune parameters in rainbow trout (Oncorhynchus mykiss)," Fish and Shellfish Immunology, vol. 32, no. 6, pp. 1083-1087, 2012.

[319] R. Fuller, "Probiotics in man and animals," Journal of Applied Bacteriology, vol. 66, no. 5, pp. 365-378, 1989.

[320] B. Spanggaard, I. Huber, J. Nielsen et al., "The probiotic potential against vibriosis of the indigenous microflora of rainbow trout," Environmental Microbiology, vol. 3, no. 12, pp. 755-765, 2001.

[321] A. Irianto and B. Austin, "Probiotics in aquaculture," Journal of Fish Diseases, vol. 25, no. 11, pp. 633-642, 2002.

[322] L. Verschuere, G. Rombaut, P. Sorgeloos, and W. Verstraete, "Probiotic bacteria as biological control agents in aquaculture," Microbiology and Molecular Biology Reviews, vol. 64, no. 4, pp. 655-671, 2000.

[323] A. Farzanfar, "The use of probiotics in shrimp aquaculture," FEMS Immunology and Medical Microbiology, vol. 48, no. 2, pp. 149-158, 2006.

[324] D. L. Merrifield, A. Dimitroglou, A. Foey et al., "The current status and future focus of probiotic and prebiotic applications for salmonids," Aquaculture, vol. 302, no. 1-2, pp. 1-18, 2010.

[325] J. Samot, J. Lebreton, and C. Badet, "Adherence capacities of oral lactobacilli for potential probiotic purposes," Anaerobe, vol. 17, no. 2, pp. 69-72, 2011.

[326] N. G. Vine, W. D. Leukes, H. Kaiser, S. Daya, J. Baxter, and T. Hecht, "Competition for attachment of aquaculture candidate probiotic and pathogenic bacteria on fish intestinal 
mucus," Journal of Fish Diseases, vol. 27, no. 6, pp. 319-326, 2004.

[327] M. Chabrillón, R. M. Rico, M. C. Balebona, and M. A. Moriñigo, "Adhesion to sole, Solea senegalensis Kaup, mucus of microorganisms isolated from farmed fish, and their interaction with Photobacterium damselae subsp. piscicida," Journal of Fish Diseases, vol. 28, no. 4, pp. 229-237, 2005.

[328] M. Chabrillón, R. M. Rico, S. Arijo, P. Díaz-Rosales, M. C. Balebona, and M. A. Moriñigo, "Interactions of microorganisms isolated from gilthead sea bream, Sparus aurata L., on Vibrio harveyi, a pathogen of farmed Senegalese sole, Solea senegalensis (Kaup)," Journal of Fish Diseases, vol. 28, no. 9, pp. 531-537, 2005.

[329] P. Díaz-Rosales, S. Arijo, M. Chabrillón et al., "Effects of two closely related probiotics on respiratory burst activity of Senegalese sole (Solea senegalensis, Kaup) phagocytes, and protection against Photobacterium damselae subsp. Piscicida," Aquaculture, vol. 293, no. 1-2, pp. 16-21, 2009.

[330] N. Pieters, J. Brunt, B. Austin, and A. R. Lyndon, "Efficacy of in-feed probiotics against Aeromonas bestiarum and Ichthyophthirius multifiliis skin infections in rainbow trout (Oncorhynchus mykiss, Walbaum)," Journal of Applied Microbiology, vol. 105, no. 3, pp. 723-732, 2008.

[331] J. N. Volff, "Genome evolution and biodiversity in teleost fish," Heredity, vol. 94, no. 3, pp. 280-294, 2005.

[332] S. Ohno, Evolution by Gene Duplication, Springer, New York, NY, USA, 1970.

[333] T. Aoki, T. Takano, M. D. Santos, H. Kondo, and I. Hirono, "Molecular innate immunity in teleost fish: review and future perspectives," in Proceedings of the 5th World Fisheries Congress on Fisheries for Global Welfare and Environment, K. Tsukamoto, T. Kawamura, T. Takeuchi, T. D. Beard Jr, and M. J. Kaiser, Eds., pp. 263-276, TERRAPUB, 2008.

[334] A. Y. Gracey and A. R. Cossins, "Application of microarray technology in environmental and comparative physiology," Annual Review of Physiology, vol. 65, pp. 231-259, 2003.

[335] A. Karsi, D. Cao, P. Li et al., "Transcriptome analysis of channel catfish (Ictalurus punctatus): initial analysis of gene expression and microsatellite-containing cDNAs in the skin," Gene, vol. 285, no. 1-2, pp. 157-168, 2002.

[336] J. L. McAuley, S. K. Linden, W. P. Chin et al., "MUC1 cell surface mucin is a critical element of the mucosal barrier to infection," Journal of Clinical Investigation, vol. 117, no. 8, pp. 2313-2324, 2007.

[337] J. Dekker, J. W. A. Rossen, H. A. Büller, and A. W. C. Einerhand, "The MUC family: an obituary," Trends in Biochemical Sciences, vol. 27, no. 3, pp. 126-131, 2002.

[338] G. Patsos and A. Corfield, "Management of the human mucosal defensive barrier: evidence for glycan legislation," Biological Chemistry, vol. 390, no. 7, pp. 581-590, 2009.

[339] M. C. Rose and J. A. Voynow, "Respiratory tract mucin genes and mucin glycoproteins in health and disease," Physiological Reviews, vol. 86, no. 1, pp. 245-278, 2006.

[340] N. Moniaux, F. Escande, N. Porchet, J. P. Aubert, and S. K. Batra, "Structural organization and classification of the human mucin genes," Frontiers in Bioscience, vol. 6, pp. D1192-1206, 2001.

[341] J. R. Gum, J. C. Byrd, J. W. Hicks, N. W. Toribara, D. T. A. Lamport, and Y. S. Kim, "Molecular cloning of human intestinal mucin cDNAs. Sequence analysis and evidence for genetic polymorphism," Journal of Biological Chemistry, vol. 264, no. 11, pp. 6480-6487, 1989.

[342] T. Lang, M. Alexandersson, G. C. Hansson, and T. Samuelsson, "Bioinformatic identification of polymerizing and transmembrane mucins in the puffer fish Fugu rubripes," Glycobiology, vol. 14, no. 6, pp. 521-527, 2004.

[343] Y. Shen, J. Zhang, X. Xu, J. Fu, and J. Li, "Expression of complement component $\mathrm{C} 7$ and involvement in innate immune responses to bacteria in grass carp," Fish and Shellfish Immunology, vol. 33, no. 2, pp. 448-454, 2012.

[344] F. Fossiez, O. Djossou, P. Chomarat et al., "T cell interleukin17 induces stromal cells to produce proinflammatory and hematopoietic cytokines," Journal of Experimental Medicine, vol. 183, no. 6, pp. 2593-2603, 1996.

[345] D. V. Jovanovic, J. A. Di Battista, J. Martel-Pelletier et al., "IL17 stimulates the production and expression of proinflammatory cytokines, IL- $\beta$ and TNF- $\alpha$, by human macrophages," Journal of Immunology, vol. 160, no. 7, pp. 3513-3521, 1998.

[346] M. Awane, P. G. Andres, D. J. Li, and H. C. Reinecker, "NF$\kappa \mathrm{B}$-inducing kinase is a common mediator of IL-17-, TNF$\alpha$-, and IL- $1 \beta$-induced chemokine promoter activation in intestinal epithelial cells," Journal of Immunology, vol. 162, no. 9, pp. 5337-5344, 1999.

[347] T. Lindenstrøm, K. Buchmann, and C. J. Secombes, “Gyrodactylus derjavini infection elicits IL- $1 \beta$ expression in rainbow trout skin," Fish and Shellfish Immunology, vol. 15, no. 2, pp. 107-115, 2003.

[348] S. F. Gonzalez, K. Buchmann, and M. E. Nielsen, "Realtime gene expression analysis in carp (Cyprinus carpio L.) skin: inflammatory responses caused by the ectoparasite Ichthyophthirius multifiliis," Fish and Shellish Immunology, vol. 22, no. 6, pp. 641-650, 2007.

[349] S. F. Gonzalez, M. O. Huising, R. Stakauskas et al., "Real-time gene expression analysis in carp (Cyprinus carpio L.) skin: inflammatory responses to injury mimicking infection with ectoparasites," Developmental and Comparative Immunology, vol. 31, no. 3, pp. 244-254, 2007.

[350] L. Y. Zhu, L. Nie, G. Zhu, L. X. Xiang, and J. Z. Shao, "Advances in research of fish immune-relevant genes: a comparative overview of innate and adaptive immunity in teleosts," Developmental and Comparative Immunology. In press.

[351] A. Lü, X. Hua, J. Xue, J. Zhu, Y. Wang, and G. Zhou, "Gene expression profiling in the skin of zebrafish infected with Citrobacter freundii," Fish and Shellfish Immunology, vol. 32, no. 2, pp. 273-283, 2012.

[352] C. Li, Y. Zhang, R. Wang et al., "RNA-seq analysis of mucosal immune responses reveals signatures of intestinal barrier disruption and pathogen entry following Edwardsiella ictaluri infection in channel catfish, Ictalurus punctatus," Fish and Shellfish Immunology, vol. 32, no. 4, pp. 816-827, 2012.

[353] M. M. Monte, T. H. Wang, M. M. Costa, N. O. Harun, and C. J. Secombes, "Cloning and expression analysis of two ROR-g homologues (ROR-gammaal and ROR-gammaa2) in rainbow trout Oncorhynchus mykiss," Fish and Shellfish Immunology, vol. 33, no. 2, pp. 365-374, 2012.

[354] F. Takizawa, E. O. Koppang, M. Ohtani et al., "Constitutive high expression of interleukin-4/13A and GATA-3 in gill and skin of salmonid fishes suggests that these tissues form Th2skewed immune environments," Molecular Immunology, vol. 48, no. 12-13, pp. 1360-1368, 2011.

[355] M. Ashburner, C. A. Ball, J. A. Blake et al., "Gene ontology: tool for the unification of biology," Nature Genetics, vol. 25, no. 1, pp. 25-29, 2000.

[356] S. F. Gonzalez, N. Chatziandreou, M. E. Nielsen et al., "Cutaneous immune responses in the common carp detected 
using transcript analysis," Molecular Immunology, vol. 44, no. 7, pp. 1664-1679, 2007.

[357] W. S. Davidson, B. F. Koop, S. J. M. Jones et al., "Sequencing the genome of the Atlantic salmon (Salmo salar)," Genome Biology, vol. 11, no. 9, article no. 403, 2010.

[358] M. L. Rise, K. R. von Schalburg, G. D. Brown et al., "Development and application of a salmonid EST database and cDNA microarray: data mining and interspecific hybridization characteristics," Genome Research, vol. 14, no. 3, pp. 478-490, 2004.

[359] J. Thorsen, B. Zhu, E. Frengen et al., "A highly redundant BAC library of Atlantic salmon (Salmo salar): an important tool for salmon projects," BMC Genomics, vol. 6, article 50, 2005.

[360] S. A. M. Martin, J. B. Taggart, P. Seear et al., "Interferon type I and type II responses in an Atlantic salmon (Salmo salar) SHK-1 cell line by the salmon TRAITS/SGP microarray," Physiological Genomics, vol. 32, no. 1, pp. 33-44, 2007.

[361] B. F. Koop, K. R. Von Schalburg, J. Leong et al., "A salmonid EST genomic study: genes, duplications, phylogeny and microarrays," BMC Genomics, vol. 9, article 545, 2008.

[362] G. Micallef, R. Bickerdike, C. Reiff, J. M. O. Fernandes, A. S. Bowman, and S. A. M. Martin, "Exploring the transcriptome of Atlantic salmon (Salmo salar) skin, a major defense organ," Marine Biotechnology, vol. 14, no. 5, pp. 559-569, 2012.

[363] M. Kircher and J. Kelso, "High-throughput DNA sequencing-concepts and limitations," BioEssays, vol. 32, no. 6, pp. 524-536, 2010.

[364] F. Goetz, D. Rosauer, S. Sitar et al., "A genetic basis for the phenotypic differentiation between siscowet and lean lake trout (Salvelinus namaycush)," Molecular Ecology, vol. 19, no. 1, pp. 176-196, 2010.

[365] J. Jeukens, S. Renaut, J. St-Cyr, A. W. Nolte, and L. Bernatchez, "The transcriptomics of sympatric dwarf and normal lake whitefish (Coregonus clupeaformis spp., Salmonidae) divergence as revealed by next-generation sequencing," Molecular Ecology, vol. 19, no. 24, pp. 53895403, 2010.

[366] M. Løvoll, J. Wiik-Nielsen, S. Grove et al., "A novel totivirus and piscine reovirus (PRV) in Atlantic salmon (Salmo salar) with cardiomyopathy syndrome (CMS)," Virology Journal, vol. 7, article no. 309, 2010.

[367] M. Salem, C. E. Rexroad, J. Wang, G. H. Thorgaard, and J. Yao, "Characterization of the rainbow trout transcriptome using Sanger and 454-pyrosequencing approaches," BMC Genomics, vol. 11, no. 1, article 564, 2010. 


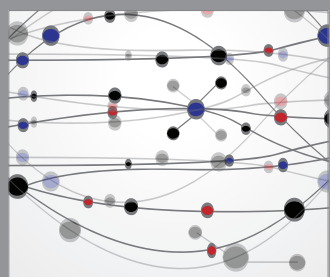

The Scientific World Journal
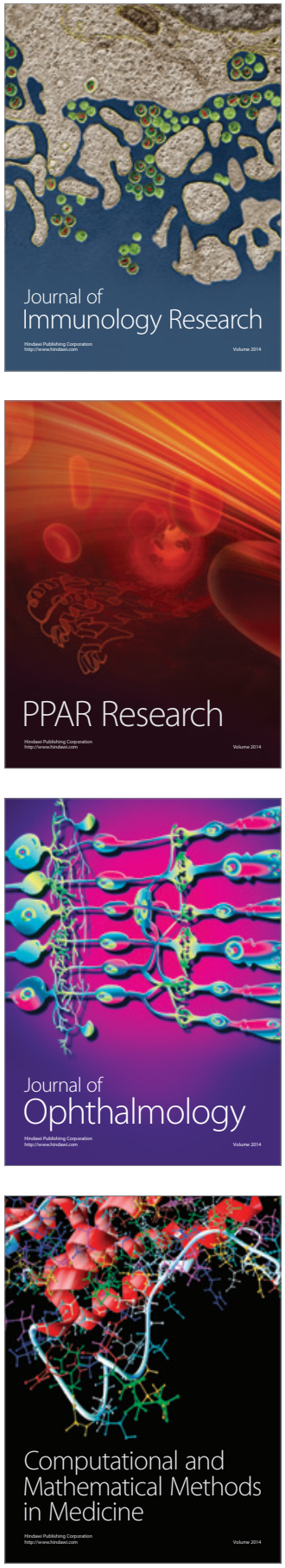

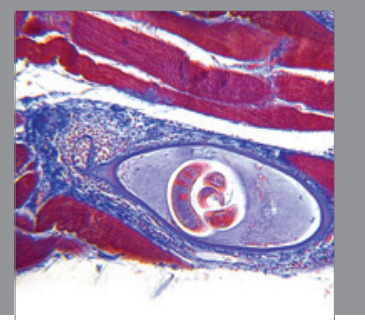

Gastroenterology

Research and Practice
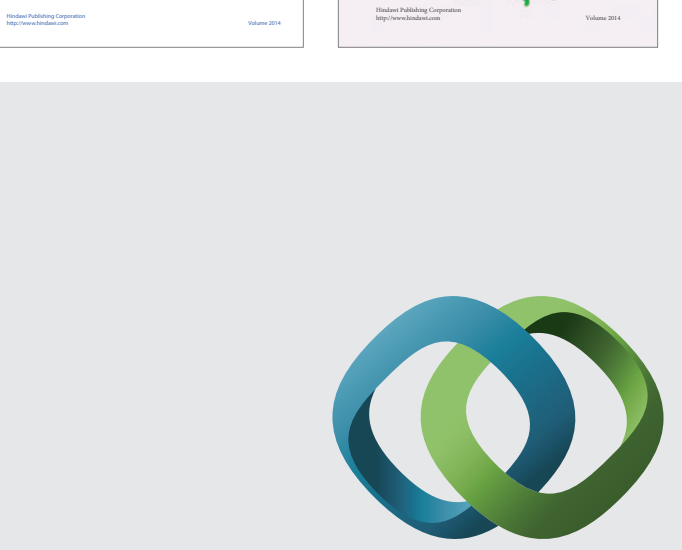

\section{Hindawi}

Submit your manuscripts at

http://www.hindawi.com
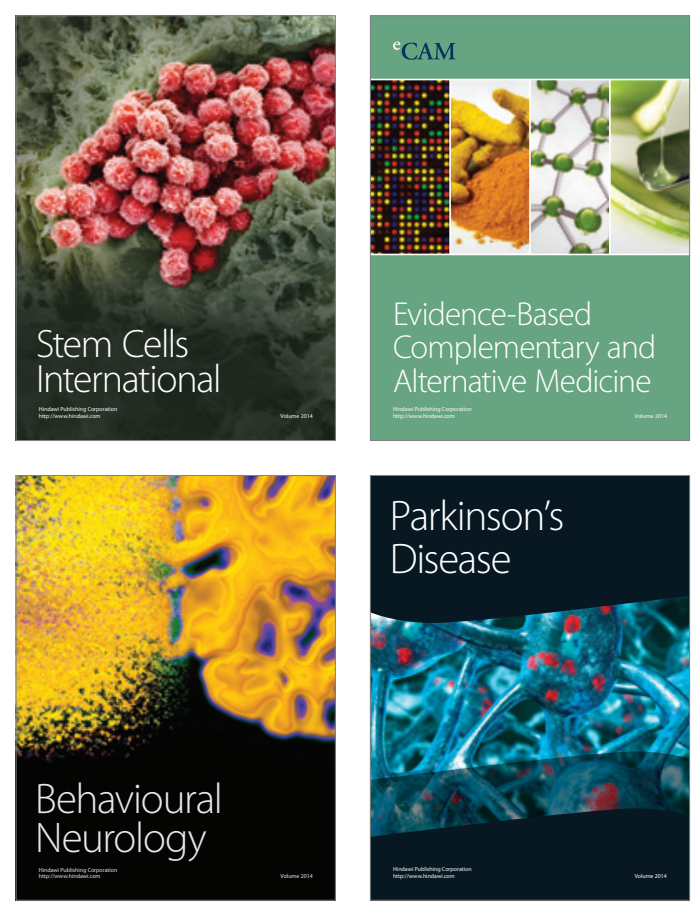

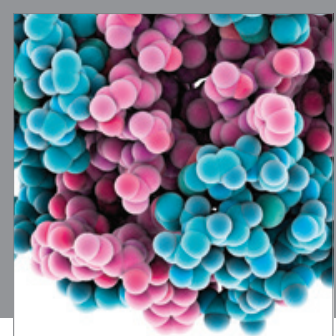

Journal of
Diabetes Research

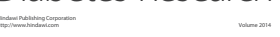

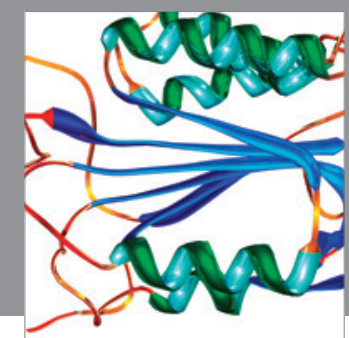

Disease Markers
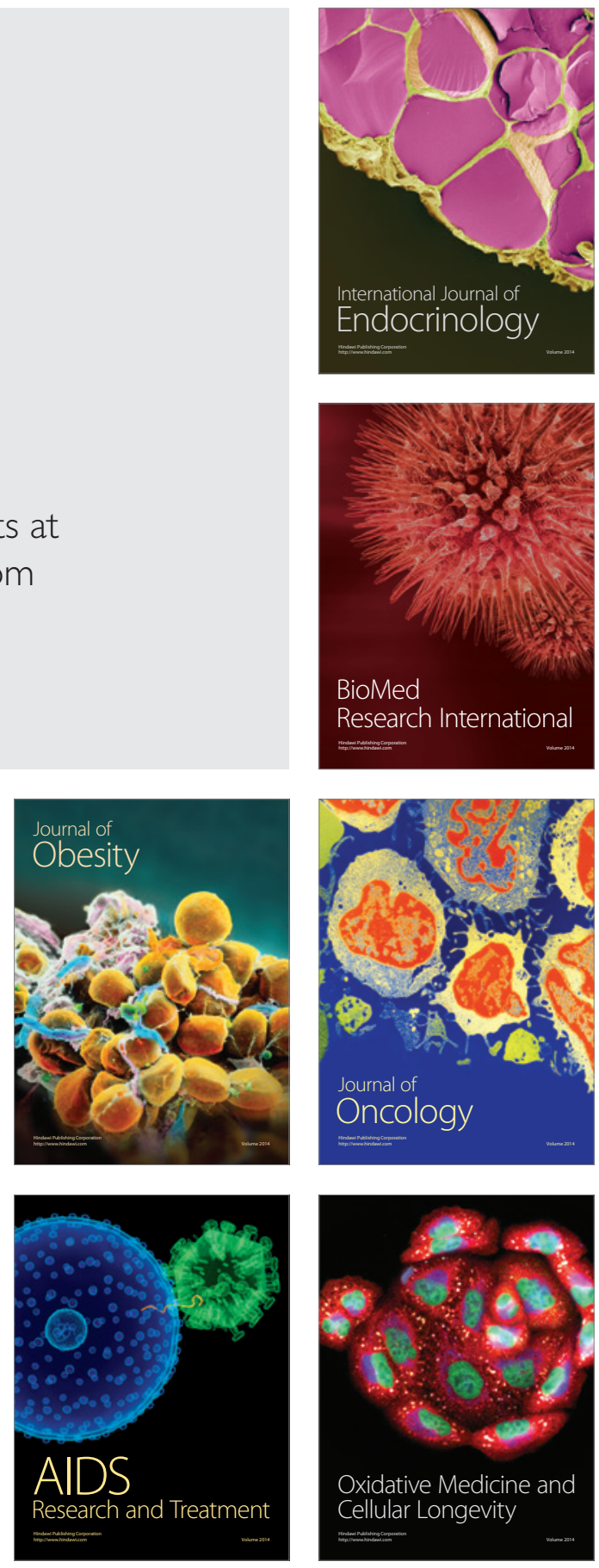